\title{
SAFIRE User's Manual
}

\author{
B. B. Glasgow* \\ W. R. Meier ${ }^{\dagger}$
}

January 12, 1987

\footnotetext{
- TRW, Redondo Beach, Calif.

${ }^{\dagger}$ Foranerly at Lawrence Livermore National Laboratory, Livermore, Calit Presently at W. J. Schafer Associates, lac., Pleasantor, Calif
}

\section{DISCLAJMER}

This repart was prepared as an account of work sponsored by an agency of the United States Government. Neither the United States Government nor any ageticy thereof, nor any of their employess, makes any warranty, express or impliod, or assumes any legal liability or responsjbility for the accuracy, completeness, of usefulness of any information, apparatus, product, of process disclosed, of sepreseints that its use wnuld not infringe privately owned rights. Reference herein to any speciīic commercial product, process, or service by trade name, trademark, manufacturer, or otherwise does not nectessarily constitute or imply its endorsement, recommendation, of favoting by the United States Government or any agency thereof. The views and opinions of authots expressed herein do not necessarily state or reflect those of the United Stales Government or any agency thereul. 
Introduction

Subroutines and their Functions Common Blocks

BANDS

BLNKTI

BL.NKT2

CAVITI

CAVIT2

CAVIT3

CAVIT4

CAVITY

CMBLDG

CMBOPC

CHHTS

CHPONC

COUTT

CURTAN

DRIVER

EXTRAT

INDCST

INOUT

OUTT

PLANTI

PLANT2

PLANT3

PLANT4

PLANT5

PLANTG

PLNT

PLTCAS

POHBAL

RINF

STUFF

TARI

TARFAC

TARGET

TENER

TEXTR1

TEXTR2

TEXTR3

TRITI

Input File

NAMELIST Input

ACCNT

CBANDS

DSYST

FUEL.

LHWIN

TASK .

Formatted Input

Input/Output (I/O) Units

Acknowledgment .

Appendix A: Example Input and Output files for SAFIRE 
Analytical models for scaling the cost and performance of inertial confinement fusion (ICF) electric-power plants have been developed and incorporated into the SAFIRE code. SAFIRE denotes systems analysis for ICF reactor economics. Volume 1 presents the details of the cost and performance scaling algorithms. This volume, Vol. 2, describes the subroutines, COMMON blocks, file handling, and input and output varlables of the code. Appendix A in this volume presents sample input and output files. Appendix 8 is an alphabetical list of variables.

The original version of this code was uritten to calculate the parameters of fusion-fission hybrids. Although the current version of the code retains: some of the hybrid-related variables and calculations, it cannot be used to analyze fusion-fission hybrids.

The SAFIRE code is available on the Mational Magnetic Fusion Energy Computer Center's Cray-1 and X-MP computers. The example input and output files described in Appendix $A$ and the source code are contained in a directory called SAFIRTAK. This directory also includes a text file called README that describes the available files and provides update information. Use FILEM to retrieve files from SAFIRTAK as follows:

filem read .7767 .saftrtak filelist

where filelist is the space-delinited list of flle names.

SAFIRE must be compiled using RCFT. The following RCFT comnand line precompiles with PRECOAP, compiles with CFT, loads with LDR, and executes the resulting controllee:

rcft p=safire,go

Before typing this line, change the name of the input file to "infile." To avoid recompiling for subsequent problems, type the following:

xsafire infile-filename

Where filename is the name of the input file if it has not already been changed to "inflle." 
The SAFIRE code is written in FORTRAN 77 and can be run on any computer that accepts the NAMELIST statement as an input option. It is written in a top-down modular style as shown in Fig. 1. The main program coordinates the overall control of the program flow, while each subroutine performs a specific function. The subroutine descriptions are listed below.

ABLATE Calculates the wall loss per pulse (ablation) of the first wall based on surface temperatures.

BLDCST Calculates the costs of bulldings and structures for Account 21.

BLOSI2 Calculates the bullaing sizes for later use in costing.

BLNKT Calculates parameters assoctated with the ICF blanket and shield systems, including effective reaction rates, zonal parameters, materlal volumes and costs, and overall dimensions of the ICF chamber.

BOPCST Calls the appropriate subroutines to calculate the balance-of-plant cost for Accounts 20,21, 23, 24, and 25.

CASBOP Calculates the power balance for the Cascade reactor.

CASCAD Calculates the Cascade chamber radius.

CASCOS Calculates the Cascade reactor costs for Accounts 21 to 26 .

CASPLT Calls the appropriate subroutines to calculate the Cascade balance of plant and costs.

CONHT9 Assigns values to materlal propertles for HT-9.

CON316 Assigns values to materlal properties for 316 stainless steel.

COSTI Calculates the final costs.

DELTAT Calculates the maximum temperature difference (TMAX-TO) in the first wall based on thermal-stress and 1iquid-1mpact fatigue Issues.

DRYCAV Calculates the necessary radius and thickness for the drywall chamber designs. Also, calculates chamber lifetimes and direct operating costs for the chamber.

EAGLE Calculates the necessary radius and thickness for the EAGLE chamber designs. Also, calculates chamber lifetimes and direct operating costs for the chamber. 
EPECST Calculates the electrical plant equipment costs for Account 25.

EXTRAC Calculates the performance and tritium inventory associated with the molten-salt tritium-extraction process.

HANDF Calculates the midplane packing fraction of the liquid lithium and the required lithium head for the HYLIFE chamber.

HIBALL Calculates the necessary radius and thickness for the HIBALL chamber designs. Also, calculates chamber lifetimes and direct operating costs for the chamber.

HIBDRI Calculates the heavy-ion-beam power requirements and direct cost.

HTSBOP Sizes the power conversion system and computes the power balance including finding the net electric power.

HTSYM Calculates several values for the heat exchanger system including: coolant temperatures, power balance, flow rates, size of steam generators, and costs associated with the system.

HYORO Computes the chamber- and blanket-flow parameters for HIBALL.

HYORO3 Computes the chamber- and blanket-flow parameters for EAGLE.

ICFBLD Calculates building and tunnel stzes.

ICFPLT Calculates power requirements and calls appropriate subroutines to calculate building sizes.

INDIR Computes parameters used to determine indirect costs and cost of electricity.

INFLAT Uses inflation factors to inflate direct capital costs and operating costs to reference-year dollars.

INIT Sets up the initialization of the program, including reading the input file and defining default values.

INITIA Determines target yield, gain, driver energy, fusion power, and repetition rate per chamber.

LFLow Calculates the lithium-flow requirements and pumping requirements.

LIBDRI Computes the efficiency, cost, and solid-angle parameters for the light-ion driver.

LLRCST Calculates the cost of land and land rights for Account 20.

LMRB Calculates the inner radius of the liquid-lithium jets to satisfy impact stress limits for the HYLIFE chamber.

LWW

Calculates the cost and lifetime parameters for lithium-wall designs for the HYLIFE chamber. 
MPECST Calculates the cost of miscellaneous plant equipment for Account 25.

QUTO Consists of an output rolitine for the first half of the longer version of the output.

OUTI Consists of an output routine for the second hialf of the longer version of the output.

OUT2 Consists of an output routine for the two short versions of the output.

PLANT Calculates integrated and global plant parameters including: power flow, direct costs, operating costs, fuel production, and tritium inventory.

POWCON Calculates gross turbtne cycle efficiency.

REACPL Calculates the liquid-metal reactor cost for Account 22.

RINNER Calculates the inner radius of the blanket for the HIBALL reactor.

SCALE Calculates the chamber size using various scailng relationships for HYLIFE. Also, calculates the required liquid-lithium effective thickness based on radiation damage.

SCALE2 Scales the chamber size using various scallng relationships for HIBALL such as displacement per atom (dpa) and helium production.

SCALE3 Scales the chamber radius with Impact stress and dpa for EAGLE.

SHELL1 Relates the driver energy to the yield and gain of heavy-ion and laser drivers for single-shell targets.

SHELL2 Relates the driver energy to the yield and gain of heavy-ion and laser drivers for double-shell targets.

SLUG Calculates the liquid-impact stress and is iteratively used by LMRO.

STMDOT Calculates the steam flow rates.

STRESS Calculates the temperature rise and stress in the first wall.

SHLDRI Computes the short-wavelength (KrF) laser performance and cost as well as final optics and lost solid-angle parameters.

TGTFAC Computes the direct cost, tritiun inventory, and a number of parameters associated with an ICF target factory.

TPECST Calculates the turbine plant equipment cost for Account 23. 
TRITFL Calculates tritium, deuterium, total hydrogen, and helium (fusion debris) burn, production, and flow rates in ICF targets, chambers, blankets, target factories, and the total piant. Also, computes unburned fuel and debris flows to vacuum and liquid-curtain systems (if applicable).

TUBES Calculates the radius, number, and cost of tubes for HIBALL.

TYPHTS Finds the character representation of the type of heat transfer system.

WALL Calculates the wall thickness based on the maximum temperature dfference. 


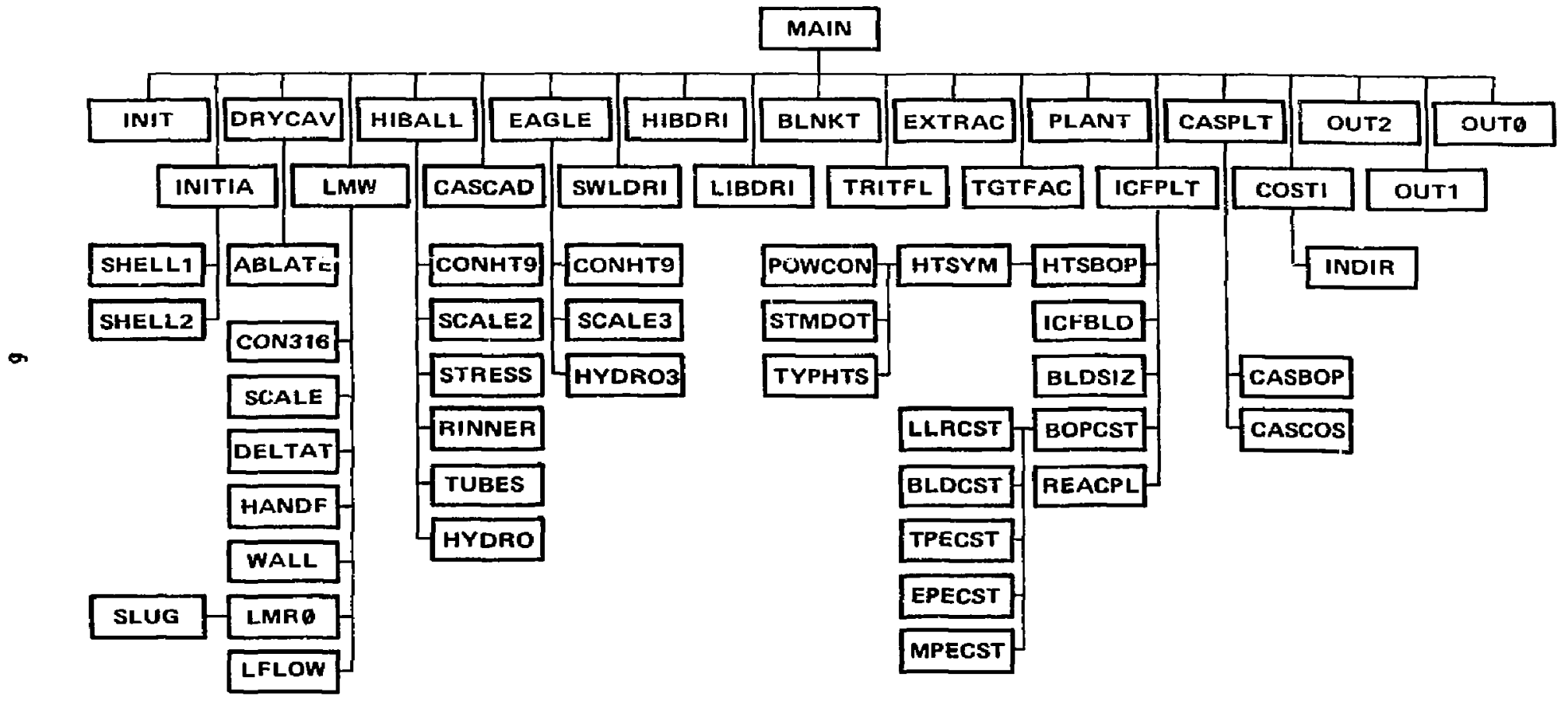

Figure 1. Program structure of the SAFIRE code. 


\section{COMHON BLOCKS}

Most of the variables used in SAFIRE are stored in COMHON blocks. Variables that:

- End with T refer to the axial-blanket region.

- End with 0 refer to the the radjal-blanket region.

- Include 1 in the name refer to the first of two types of material.

- Include 2 in the name refer to the second of two types of material. The COMHON blocks are listed below with the definitions of the variables and the units.

\section{COMNOA / BAMDS I}

CBMO Total direct cost of fabricated radial-blanket materials (M\$).

CBMT Total uirect cost of fabricated axial-blanket materials (M\$).

OBO(6) Array of radial-zone thicknesses $(\mathrm{m})$.

DBT(6) Array of axial-zone thicknesses (m).

EMMO Fusion neutron energy multiplication in the radial blanket.

EMMT Fusion neutron energy multiplication in the axial blanket.

EMO(6) Array of radial zonal neutron-energy multiplication factors.

EMT(6) Array of axial zonal neutron-energy multipication factors.

FWCO Solid-angle fraction assoclated with the radial blanket.

FWCT Solid-angle fraction associated with the axial blanket.

OCBMO Operating cost to replace radial-blanket structure ( $M \$ / \mathrm{yr})$.

OCBMT Operating cost to replace axial-blanket structure (M\$/yr).

PDENSO(6) Array of zonal power densities in radial blanket $\left(\mathrm{MW}_{\mathrm{t}} / \mathrm{m}^{3}\right)$.

POENST(6) Array of zonal power densities in axtal blanket $\left(M H_{t} / \mathrm{m}^{3}\right)$.

PWRBO(6) Array of zonal powers in radial blanket $\left(M H_{t}\right)$.

PWRBT(6) Array of zonal powers in axial blanket $\left(\mathrm{NH}_{t}\right)$. 
ROSO Outer radius of radial blanket (m).

ROST Outer radius of axial blanket $(m)$.

TEMM Average neutron-energy multiplication in blanket.

TPO Tritium production in radial blanket ( $\mathrm{kg} / \mathrm{yr})$.

TPT Tritium production in radial blanket ( $\mathrm{kg} / \mathrm{yr}$ ).

TRELO Tritium breeding ratio in radial blanket.

TRELT Tritium breeding ratio in axial blanket.

ITP Total tritium production per chamber (kg/yr).

UCOBSO $(6,6)$ Array of unit direct costs for radial-bianket materfais by zone $\left(\mathrm{M} S / \mathrm{m}^{3}\right)$.

UCOBST $(6,6)$ Array of unit direct costs for axial-blanket materials by zone $\left(M S / m^{3}\right)$.

VEO(6) Array of radial-blanket zone volumes $\left(m^{3}\right)$.

VBT(6) Array of axial-blanket zone volunes $\left(\mathbf{m}^{3}\right)$.

$\operatorname{VBSRO}(6,6)$ Array of radial-blanket volumes by zone and materfal $\left(\mathrm{m}^{3}\right)$.

$\operatorname{VBSRT}(6,6)$ Array of axial-blanket volumes by zone and material $\left(\mathrm{m}^{3}\right)$.

VFBSO $(6,6)$ Array of radial-blanket material volume fractlons by $z$ one.

VFBST $(6,6)$ Array of axial-blanket material volume fractions by zone.

HCAOJO Solid-angle fraction for radial blanket.

WCADJT Solid-angle fraction for axial blanket.

\section{COMNON / BLMKTI /}

SALREM Net avaliable solid-angle fraction for breeding.

\section{COMnN / BLAKT2 ;}

DAGO Gap between the first vall and radial blanket $(\mathrm{cm})$.

DRGT Gap thickness between the first wall and the axial blanket (cm). 
DCBM Total direct cost of blanket materials per chamber (M\$).

MCOOLO Material number for radial-blanket coolant.

MCOOLT Material number for axial-blanket coolant.

MSTROI Material number for radial-blanket structure: component 1.

MSTRO2 Material number for radial-blanket structure: component 2.

MSTRO3 Material number for radial-blanket structure: component 3.

MSTRO4 Materlal number for radial-blanket stiucture: component 4.

MSTRT1 Material number for axial-blanket structure: component 1.

MSTRT2 Material number for axial-bla :.et structure: component 2.

MSTRT3 Materfal number for ax|al-blanket structure: component 3.

MSTRT4 Material number for axial-blanket struckure: component 4.

TIRRDO Radial-blanket iriadiation time (full power years).

TIRROT Axial-blanket irradiation time (full fower years).

TO

Tritium atoms bred per neutron in radial blanket at $180 \%$ solid angle.

IT Tritium atoms bred per neutron in axial blanket at $100 \%$ solid angle.

TOCBH Total operating cost of blanket materials per chamber (M\$).

\section{COMHON / CAVITI /}

ASTRLO Actual radial-blanket-structure lifetime for neutron damage at input plant capacity (yr).

ASTRLT Actual axial-bianket-structure lifetime for neutron damage at input plant capacity (yr).

FWT Actual first-wall thickness including liner (mm).

HDRATI Height to diameter ratio for ISHAPE equa?s 2.

ISHAPE Switch for ICF chamber shape:

1 sphere

2 cylinder 


\section{CONOW / CAVIT2 I}

AMLIFE Actual first-wall lifetime (yr).

AWLIFN Lifetime based on first-kall neutron damage (yr).

CAREA Actual chamber front-surface area $\left(\mathrm{m}^{2}\right)$.

CVOLUM Chamber volume $\left(\mathrm{m}^{3}\right)$.

DCFWAL Direct cost of first wall (M\$).

FLONG Fraction of fusion energy associated with neutrons.

FLUFW Fluence limit for neutron damage to first wall (MN०yr/m²).

FLUSTO Fluence limit for neutron damage to radial-blanket structure $\left(\right.$ MHoyr $\left./ \mathrm{m}^{2}\right)$.

FLUSTT Fluence limit for neutron damage to axial-blanket structure $\left(M H \circ y r / m^{2}\right)$.

FWPWRA Maximum first-wall power density $\left(\mathrm{W} / \mathrm{m}^{2}\right)$.

GASDEN Lithium vapor density $\left(\mathrm{g} / \mathrm{cm}^{3}\right)$.

MNWLLD Maximum neutron wall loading including capacity factor $\left(\mathrm{WW}^{2} / \mathrm{m}^{2}\right)$.

OCFWAL Operating cost of ICF first wall (M\$/yr).

RADNFW First-wall radius based on neutron-damage limit (m).

RADNSO Radial-blanket radius based on neutron-damage 1imit (m).

RADNST Axial-blanket radius based on neutron-damage limit (m).

RHOW2 First-wall-structure density $\left(\mathrm{g} / \mathrm{cm}^{3}\right)$.

STRLFO Desired radial-blanket-structure lifetime (yr).

STRLFT Desired axial-blanket-structure lifetime (yr).

WCST2 Unit cost of the fabricated first wall $(\$ / \mathrm{kg})$.

$\times 2$

Equivalent solid thickness of first-wall structural material (mm).

\section{CONOWI / CAVIT3 I}

ALPSAR Maximum fraction of sacrificial liner allowed to ablate per shot.

AWLIFA Lifetime based on first-vall ablition (yr). 


\begin{tabular}{|c|c|}
\hline DTPULS & Temperature rise of front surface for each pulse $(K)$. \\
\hline EFFWLS & Effective wall loss for each pulse, excluding recondensation (mm). \\
\hline EFWLLM & Maximum thickness of THSACR to ablate per shot $(\mathrm{mm})$. \\
\hline FRECON & $\begin{array}{l}\text { Fraction of ablated materials uniformly recondensed on the wall } \\
\text { to reduce abiation loss. }\end{array}$ \\
\hline FSHORT & $\begin{array}{l}\text { Fraction of fuston energy absorbed on front surface of the first } \\
\text { wall. }\end{array}$ \\
\hline IRAD & $\begin{array}{l}\text { Final damage-criterion-type index: } \\
1 \text { ablation } \\
2 \text { neutron damage } \\
3 \text { neutron damage (blanket) } \\
4 \text { externally input constraint }\end{array}$ \\
\hline IKDSGN & $\begin{array}{l}\text { Swltch for first-wall-structure thickness: } \\
1 \text { fixed } \\
2 \text { calculated }\end{array}$ \\
\hline MINRAD & Minimum acceptable chamber radius (m). \\
\hline HLOSS & Sacrificial-liner mass loss for each pulse $(g)$. \\
\hline RADISA & Hinimum chamber radius to satisfy ablation criterion $(m)$. \\
\hline TO & $\begin{array}{l}\text { Maximum temperature of outside of first wall for boundary } \\
\text { condition for ablation calculation; usually the first-wail } \\
\text { coolant temperature }\left({ }^{\circ} \mathrm{C}\right) \text {. }\end{array}$ \\
\hline THSACR & Thickness of sacrificial ablation material (mm). \\
\hline TMAX & Front surface temperature to ablate WLOSS $(K)$. \\
\hline VFFWC & First-wall-coolant volume fraction. \\
\hline VFFWS & Structural volume fraction of first wall. \\
\hline WLIFE & Desired first-wall lifetime at $100 \%$ capacity factor (yr). \\
\hline HLOSS & Actual permissible wall loss at each pulse $(\mathrm{mm})$. \\
\hline
\end{tabular}

\section{COMnON / CAVIT4 /}

BFUSPR Fusion neutron power passed to blanket $\left(\mathrm{MH} / \mathrm{m}^{2}\right)$.

FWPWR Fusion power collected in first wall ( $\left(W_{t}\right)$. 


\section{COWNON I CAVITY I}

$\mathrm{Cl}$

C2

C3

C4

C5

C6

C7

C8

C9

C10

CCl(3) Corresponds to $\mathrm{Cl}$.

CC2(3) Corresponds to $\mathrm{C2}$.

CC3(3) Corresponds to C3.

CC4(3) Corresponds to C4.

CC5(3) Corresponds to C5.

CC6(3) Corresponds to $\mathrm{C} 6$.

CC7(3) Corresponds to $\mathrm{C7}$.

CCB(3) Corresponds to CB.

CCg(3) Corresponds to C9.

$\mathrm{CClO(3)}$ Corresponds to $\mathrm{ClO}$.

CCP(3) Array of $C P$ values $\left(K \cdot m^{2} \cdot 5 / M 3\right)$.

CCX2(3) Array of $\left(X_{2}\right.$ values (mom/MJ).

CP Material constant narmalized to reference destgn for temperature rise of sacrificial liner for each pulse $\left(\mathrm{K} \cdot \mathrm{m}^{2} .5 / \mathrm{MJ}\right)$.

$\mathrm{CX} 2$

First-wall thickness normalized constant (mom/hu). 


\begin{tabular}{|c|c|}
\hline FLU(3) & Array of flueice values ( $\mathrm{H} / \mathrm{h} \cdot \mathrm{yr} / \mathrm{m}^{2}$ ). \\
\hline K? & Thermal conductivity of sacrificial liner $(M H / m-K)$. \\
\hline K2. & Thermal conductivity of first-wall structure $(M H / m m \circ K)$. \\
\hline RHOHI & Sacrificlal liner density $\left(\mathrm{g} / \mathrm{cm}^{3}\right)$. \\
\hline RRHONI (3) & Array of RHOHl values $\left(\mathrm{g} / \mathrm{cm}^{3}\right)$. \\
\hline RRHOH2(3) & Array of RHOH2 values $\left(\mathrm{g} / \mathrm{cm}^{3}\right)$. \\
\hline NCSTI & Untt cost of the fabricated sacrificlal liner $(\$ / \mathrm{kg})$. \\
\hline WHCST1(3) & Array of cost values $(s / \mathrm{kg})$ \\
\hline WHCST2(3) & Array of $H C S T 2$ values $(\$ / \mathrm{kg})$. \\
\hline$X 1$ & Beginning of cycle thickness of sacrificial liner $(\mathrm{mm})$. \\
\hline $\mathrm{XK} 1(3)$ & Array of $\mathrm{Kl}$ values $(H W / \mathrm{mm} \cdot \mathrm{K})$. \\
\hline XK2(3) & Array of $K 2$ values $(H W / m m \circ K)$. \\
\hline$x \times 1(3)$ & Array of XI Values $(\mathrm{mm})$. \\
\hline$x \times 2(3)$ & Array of $\lambda 2$ values $(\mathrm{mm})$. \\
\hline
\end{tabular}

\section{COMON / CHBLDG /}

- ABLDG; Total area of all the bulldings $\left(\mathrm{m}^{2}\right)$.

APSB Area of the power supply building $\left(\mathrm{m}^{2}\right)$.

ARCB Area of the reactor containment building $\left(\mathrm{m}^{2}\right)$.

VBC Volume of the control building $\left(n^{3}\right)$.

VBLDG Total volume of all the bufldings $\left(\mathrm{m}^{3}\right)$.

VMSS Volume of the miscellaneous structures $\left(m^{3}\right)$.

VPSB Volume of the power supply building $\left(\mathrm{m}^{3}\right)$.

VRABNR Volume of the reactor auxlliary building (nonradioactive) $\left(m^{3}\right)$.

VRABR Volume of the reactor auxiliary building (radioactive) $\left(\mathrm{m}^{3}\right)$.

VRCB Volume of the reactor containment buflding $\left(\mathrm{m}^{3}\right)$.

VRSB Volume of the steam reactor service building $\left(\mathrm{m}^{3}\right)$. 
VSGB Volume of the steam generator building $\left(\mathrm{m}^{3}\right)$.

VTGB Volume of the turbine generator building $\left(\mathrm{m}^{3}\right)$.

VTUN Volume of the beam tunnels $\left(\mathrm{m}^{3}\right)$.

\section{COWnON / CABOPC I}

CEPE Cost of electric plant equipment for Account 24 (M\$).

CHRS Cost of main heat rejection equipment for Account 26 (M5).

CLLR Cost of land and land rights for Account 20 (MS).

CHPE Cost of miscellaneous plant equipment for Account 25 (M\$).

CSSF Cost of structures and site facilities for Account 21 (M\$).

CTPE Cost of turbine plant equipment for Account 23 (H\$).

\section{CONWN / CAHTS /}

CTHTS Total cost of heat-transport-system components for Account 22.02 (M\$).

DC Pulse duty cycle.

IBCLT Switch identifying blanket-coolant type:

1 Li

$2 \mathrm{Na}$

$6 \mathrm{PbLi}$

NSG Number of steam generator units.

PB Power generated in blanket $\left(M H_{t}\right)$.

PCPP Coolant-pumping-power requirement $\left(M_{e}\right)$.

PS Turbine steam pressure (MPa).

PSG Power rating for steam generators $\left(W_{t}\right)$.

QREJ Thermal power rejected from cycle $\left(M_{t}\right)$.

TOFF Off time between pulses (s).

TS Turbine steam temperature ("C).

TSUP Minimum steam temperature for superheat cycle ( $\mathrm{C})$.

VCB Volume of blanket coolant $\left(\mathrm{m}^{3}\right)$.

WS Steam flow rate to the turbine $(\mathrm{kg} / \mathrm{s})$. 


\section{COMNON / CAPOAN /}

\begin{tabular}{|c|c|}
\hline ELBOP & Electric power required to run balance of plant $\left(\mathrm{MW}_{\mathrm{e}}\right)$. \\
\hline ELGENL & $\begin{array}{l}\text { General type electric power requirements to run the driver } \\
\left(M W_{e}\right) \text {. }\end{array}$ \\
\hline ELSPEC & Special power requirements for driver $\left(M W_{e}\right)$. \\
\hline FEGRS & Gross electric power production $\left(W / H_{e}\right)$. \\
\hline GETA & Generator efficiency. \\
\hline ICYCLE & $\begin{array}{l}\text { Switch for determining the type of cycles: } \\
\text { I saturated steam } \\
2 \text { superheated steam }\end{array}$ \\
\hline NL.OOP & $\begin{array}{l}\text { Switch for setting the cooling loop type: } \\
\text { 1 single loop } \\
2 \text { double loop }\end{array}$ \\
\hline NTGU & Number of turbine generator units. \\
\hline PEGRS & Gross electric power $\left(M H_{e}\right)$ \\
\hline PENET & Net electric power production $\left(W_{e}\right)$. \\
\hline PGRSTH & Thermal power per plant $\left(\boldsymbol{N}_{\mathrm{H}} \mathrm{t}_{\mathrm{t}}\right)$. \\
\hline PIG & Power rating per turbine generator $\left(M H_{e}\right)$. \\
\hline TETA & Turbine cycle efficlency. \\
\hline
\end{tabular}

COMWON / COUTT I

ACCT Character representation of the account names.

ATITLE Character variable for the title of the current file.

CTYP Character representation of the coolant type.

MATLO(6) Material character identifiers for the radial blanket--up to six materials.

MATLI(6) Material character identifiers for the axial blanket--up to six materials.

SCT Character representation of the steam cycle.

TTSU Character representation of the cooling system description. 
COMON / CURTAK /

\begin{tabular}{|c|c|}
\hline ALPH & Thermal expansion coefficient $\left(\mathrm{K}^{-1}\right)$. \\
\hline ALPHI & Normalized constant for impact stress. \\
\hline AUXPH & Auxiliary power $\left(\mathrm{NW}_{\mathrm{e}}\right)$. \\
\hline C & Speed of sound in lithium $(m / s)$. \\
\hline $\mathrm{CHI}$ & Preexponential for IH scaling. \\
\hline $\mathrm{CH} 2$ & Exponentlal for IH scaling. \\
\hline CHII & Thermal-stress-profile constant. \\
\hline CRHI & Preexponential for IRW scaling. \\
\hline CRH2 & Exponentlal for IRH scaling. \\
\hline DTIHX & Constant used to calculate intermediate heat exchanger flow rate. \\
\hline DTLITH & Lithium energy change per pulse $(M J)$. \\
\hline EBLK & Total energy in blanket (MJ). \\
\hline ELI & Total energy in lithium (MJ). \\
\hline EN & Maximum neutron energy in 13 thism per puise. \\
\hline$F$ & Calculated lithium fractional coverage. \\
\hline $\mathrm{Fl}$ & Displacement per atom (dpa) limit constant. \\
\hline$F 2$ & Atomic-parts-per-mitlion (appm) helium limit constant. \\
\hline F3 & Constant used for maximum Impact stress calculations. \\
\hline F4 & Constant used for yield stress linit calculations. \\
\hline FINJ & Fractional area coverage at inlet. \\
\hline FLOW & Volume flow of lithium in the chamber $\left(\mathrm{m}^{3} / \mathrm{s}\right)$. \\
\hline FLWIHX & IHX lithium flow $\left(\mathrm{m}^{3} / \mathrm{s}\right)$ \\
\hline FMIN & Minimum lithium fractional midplane coverage. \\
\hline GAMH & Grijneisen coefficient. \\
\hline GN & Polsson's ratio. \\
\hline
\end{tabular}




\begin{tabular}{|c|c|}
\hline HEADL & Lithtum head $(m)$. \\
\hline HGT & Chamber height $(m)$. \\
\hline IDPA & $\begin{array}{l}\text { Damage limit designator: } \\
\text { appm is limiting } \\
1 \text { dpa is limiting }\end{array}$ \\
\hline IH & $\begin{array}{l}\text { Scalling option switch for the chamber height. } \\
1 \text { scales as the square root of fusion power } \\
2 \text { scales as the square root of target yield } \\
3 \text { scales as fusion power raised to the } \mathrm{CH} 2\end{array}$ \\
\hline IRW & $\begin{array}{l}\text { Scaling option switch for wall radius. } \\
1,2 \text { are the same as for IH } \\
3 \text { scales as fuston power ralsed to the CHW2 }\end{array}$ \\
\hline PBLIM & Evaporated mass of 11 thium per shot $(\mathrm{kg})$. \\
\hline PUMPHD & Pumping head for TFLOW (m). \\
\hline RFLOH & Lithium flow in the reflector $\left(\mathrm{m}^{3} / \mathrm{s}\right)$. \\
\hline RHO & Liquid-lithium density $\left(\mathrm{kg} / \mathrm{m}^{3}\right)$ \\
\hline$R \emptyset$ & Inner raotius of lithium fets $(\mathrm{m})$. \\
\hline SI (3) & Impact stress coefficients. \\
\hline SIGMA & Same as SIMP. \\
\hline SIMP & Calculated max!mum impact stress. \\
\hline STH & Calculated thermal stress. \\
\hline $\operatorname{sY}(3)$ & Yield stress coefficients. \\
\hline TCOST & Cost of the HIBALL tubes (M\$). \\
\hline TLI & Liquid-lithium operating temperature $(K)$. \\
\hline TNUM & Number of HIBALL tubes. \\
\hline TOTFLL & Total lithium flow $\left(\mathrm{m}^{3} / 5\right)$. \\
\hline TRADIS & Tube radius (m). \\
\hline UL & Energy attenuation coefficient. \\
\hline VELINJ & Injection velocity of 11 thiun $(\mathrm{m} / \mathrm{s})$. \\
\hline VELMF & Hidplane velocity of lithlum $(\mathrm{m} / \mathrm{s})$. \\
\hline
\end{tabular}


VOLCHB Lithium volume in head $\left(\mathrm{m}^{3}\right)$.

WALLC Constant multiplier for wall temperature rise.

XL Effective lithium thickness (m).

XLAMOA Constent used in calculating the lithlum-siug size.

YOUNGM Young's modulus (MPa).

\section{COMON / DRIVER /}

ANOT KrF-driver energy-scaling exponent.

BNOT Constant used to determine the KrF-Uriver cost scaling with puise rate.

CNOT KrF-driver reference cost (\$).

OCDRIV Dfrect cost of an ICF driver system (MS).

DCHIB1 Heavy-1on-beam cost-scailing coefficient I (MS).

DCHIB2 Heavy-ion-bean cost-scaling exponent.

OCLIB1 Light-ion-bean cost-scalfing coefficient 1 (MS).

DCLI82 Light-ion-beam cost-scaling exponent.

DCTRCK Direct cost of a T,D,A system per chamber (MS).

DFHAG1 Distance between first wall and beam exit from final focusing magnet (m).

DFMAG2 Length of final focusing magnet $(m)$.

DPPC Input power to driver $\left(M H_{e}\right)$.

EONOT KrF-driver reference energy (MJ).

EPS Required input energy to driver per shot (MJ).

ETAD Driver efficiency.

ETAHIB Efficiency of the heavy-ion-bean driver.

ETANOT KrF-driver reference efficiency.

FLUOPT Fusion-power fluence limit for final optics (MN-yr/m $/ \mathrm{R}^{2}$ ).

FNUM Calculated f/number of final optics. 


\begin{tabular}{|c|c|}
\hline FNUMAX & Maximum f/number for final optics. \\
\hline FOCUSL & Distance between focusing magriet and chamber $(m)$. \\
\hline HIBCRA & Distance between focusing magnet and chamber center $(m)$. \\
\hline HIBEAM & Radius of heavy-ion-team leaving final-focusing-magnet exit $(\mathrm{cm})$. \\
\hline IDRIVE & $\begin{array}{l}\text { Switch for driver type: } \\
1 \text { short wavelength liser } \\
3 \text { heavy-ion beam } \\
4 \text { light-ion bean }\end{array}$ \\
\hline KDRIV & $\begin{array}{l}\text { Switch to calculate driver efficiency: } \\
1 \text { do calculation } \\
\text { use input value }\end{array}$ \\
\hline KOPTIC & $\begin{array}{l}\text { Switch to calculate the radius of the final optics: } \\
1 \text { do calculations } \\
\text { use input value }\end{array}$ \\
\hline NBEAN & Number of final beams per chamber. \\
\hline NYRHIB & Year in which heavy-ion-beam cost estimates originated. \\
\hline NYRLIB & Year in which light-ion-beam cost estimates originated. \\
\hline NYRSWL & Year in which laser cost estimates originated. \\
\hline OOL & Optical damage 1 timit $\left(\mathrm{J} / \mathrm{cm}^{2}\right)$. \\
\hline OPTICI & Radius of final optics (m). \\
\hline OPTICR & Radius of final optical focusing surface (cm). \\
\hline OPTLIF & Desired lifetime of final optics $(y r)$ \\
\hline PCNOT & Constant used to determine the KrF-driver efficiency. \\
\hline RDNOT & KrF-driver reference pulse rate $(\mathrm{Hz})$. \\
\hline RRPD & Shot repetition rate per driver $(\mathrm{Hz})$. \\
\hline SANGL & Solid angle associated with all beams (steradians). \\
\hline TAU & KrF-driver pulse length (ns). \\
\hline TAUNOT & KrF-driver reference pulse length (ns). \\
\hline
\end{tabular}




\section{COHON / EXTRAT I}

GPTBRP Tritium breeding rate in total plant $(\mathrm{g} / \mathrm{s})$.

GSDUBL Deuterium breeding rate in total plant $(\mathrm{g} / \mathrm{s})$.

GSTUBL Unburned tritium flow to liquid-metal curtain $(\mathrm{g} / \mathrm{s})$.

\section{CONOW / INDCST I}

CDOM Current-dollar levelized operation and maintenance cost (expressed as a fraction of $T O C$ ).

CDOMR Constant-dollar levelized operation and maintenance cost (expressed as a fraction of TOC).

CE Current-dollar cost of electricity $\left(\mathrm{mill} / \mathrm{s} / \mathrm{kW}_{\mathrm{e}}\right)$.

CER Constant-dollar cost of electricity $\left(m+11 \mathrm{~s} / \mathrm{kW} \mathrm{W}_{\mathrm{e}}\right)$.

CINVT Total investment cost $\left(\mathrm{MS}_{\mathrm{S}} / \mathrm{kW}_{\mathrm{e}}\right)$.

CLEVI Levelized cost factor.

CONDOL Switch to convert to constant-dollar ffxed charge rate if CONDOL equals 1 .

CONTIM Construction time (yr).

CostM After tax cost of money $\left(y r^{-1}\right)$.

DUCOST Deuterium cost $(\$ / \mathrm{kg})$.

ERATE Escalation rate $\left(\mathrm{yr}^{-1}\right)$.

FCCOHS Fraction of capital from comonon stock.

FCDEP Fraction of capital from debt.

FCPEFS Fraction of capital from preferred stock.

FCRATE Current-dollar fixed charge rate $\left(y^{-1}\right)$.

FCRATR Constant-dollar fixed charge rate $\left(\mathrm{yr}^{-1}\right)$.

FUELC Current-dollar fuel cost (mills/M-h).

FUELCR Constant-dollar fuel cost (mills/mw-h).

GINF General inflation factor $\left(y r^{-1}\right)$. 
LICOST Lithium cost $(\$ / \mathrm{kg})$.

NUNIT Number of units per plant.

PCENT(7) Interest rate during construction ( $\left.\mathrm{yr}^{-1}\right)$.

PLF Power plant life (yr).

PTAXR Annual property tax rate $\left(y r^{-1}\right)$.

REALCM Real cost of money $\left(y r^{-1}\right)$.

RIODEP Interest rate on debt $\left(y r^{-1}\right)$.

RRCOMS Rate of return on common stock (yr-1).

RRPEFS Rate of return on preferred stock $\left(y r^{-1}\right)$.

T6BR Tritium breeding ratio from $6 \mathrm{Li}$.

TAXR Effective income tax rate $\left(y r^{-1}\right)$.

TOC Total operating costs (M\$).

\section{CONHON / INOUT /}

OCEXTR . Direct cost of an extractor unit of capacity CAPEX (M\$).

IPRINT Switch to print NAMELIST parameters if IPRINT is greater than 1.

NYRBNK Year in which blanket materials costs originated.

IYRDCA Year in which chamber materials costs originated.

NYREX Year in which extractor cost estimate originated.

NYRTF Year in which the target factory cost estimates originated.

NYRTRC Year in which tracking, delivery, and alignment $(T, D, A)$ system costs originated.

COMNON / OUTT /

ACCOST Costs of the various accounts (MS).

ATUN Area of the beam turnels $\left(m^{2}\right)$.

C2106 Total cost of Account 21.06 .

CAW Cost of air, water, and steam equipment (M\$). 
Cost of the control building (M\$).

Cost of the communications equipment (M\$).

Cost of the condensing equipment (M\$).

Cost of the cooling system structure (M\$).

Cost of the direct conversion building (M\$).

Cost of electrical structures and wiring (M\$).

CFF

Cost of electrical furnishing and fixtures (M\$).

Cost of the feed heating systems (Ms).

CIC

cost of the instrumentation and control (MS).

Direct investment cost $\left(\mathrm{MS} / \mathrm{KH}_{2}\right)$.

CK2

Cost of the tracking and alignment system (K\$).

CK4

Cost of the first-wall system (M\$).

CK5

Cost of the tritium extraction system (MS).

CK6

Cost of the blanket and shield (M\$).

CME

Cost of the main-heat-condenser mechanical equipment (M\$).

CMI Cost of miscellaneous turbine plant equipment (M\$).

CMSS Cost of miscellaneous structures bullding costs (M\$).

COE Cost of electricity $(q / \mathrm{kH} h \mathrm{~h})$.

COPER Current-dollar operating costs $\left(m i 11 s / k_{\mathrm{e}} \mathrm{h}\right)$.

COPERR Constant-dollar operating costs $\left(m i l l s / k_{e} h\right)$.

COSHTS An array containing the costs of the subsystems of the heat transport systems (MS).

CPC Cost of power and control wiring for the electric plant (M\$).

CPE Cost of protective equipment for the electric plant (M\$).

CPSB Building and structure poxer supply and energy storage building costs (MS).

CRABNR Cost of nonradioactive auxillary building (M\$).

CRABR Cost of the radioactive auxiliary building (M\$). 


\begin{tabular}{|c|c|}
\hline CRCB & Cost of the reactor containment building (M\$). \\
\hline CRET & Current-dollar capital return (mills. $\mathrm{kW}_{\mathrm{e}} \mathrm{h}$ ). \\
\hline CRETR & Constant-dollar capital return $\left(m_{i} i l s / \mathrm{kW}_{\mathrm{e}} \mathrm{h}\right)$. \\
\hline CRSB & Cost of the reactor service building (M\$). \\
\hline CS & Cost of the nain heat-condenser structures (M\$). \\
\hline CSB & Cost of the switchboards (M\$). \\
\hline CSGB & Cost of the steam generator building $(M \$)$. \\
\hline CSGG & Cost of the switch gear (M\$). \\
\hline $\operatorname{CSI}$ & Cost of site improvement and facilities $(M \$)$. \\
\hline $\operatorname{css}$ & Cost of the station service equipmerit (M\$). \\
\hline CTG & Cost of the turbfi.s nemerators (N\&) \\
\hline CTGB & Cost of the turbine generator building ( $M \$$ ). \\
\hline CTL & Cost of the transportation and lift equipment (M\$). \\
\hline CTUN & Cost of the tunriels (M\$). \\
\hline CWH & Cost of the waste water-treatment equipment (H\$), \\
\hline DELPB & Blanket-coolant pressure drop (MPa). \\
\hline DELTC & Coolant temperature rise across blanket $\left({ }^{\circ} \mathrm{C}\right)$. \\
\hline ENET & Net electric energy $\left(G W_{e} h\right)$ \\
\hline EXTEMP & Blanket-coolant exit temperature $\left({ }^{\circ} \mathrm{C}\right)$ \\
\hline FELBOP & $\begin{array}{l}\text { Fraction of gross electric power needed to run the balance of } \\
\text { plant. }\end{array}$ \\
\hline II & Used for internal tracking of coolant type. \\
\hline I2 & Used for internal tracking of the cooling system description. \\
\hline 13 & Used for internal tracking of the steam generator type. \\
\hline NN & Number of heat transport systems. \\
\hline PIN & Blanket-coolant inlet pressure (MPa). \\
\hline PPFR & $\begin{array}{l}\text { Maximum allowable fraction of gross electric power that is used } \\
\text { for coolant pumping power. }\end{array}$ \\
\hline
\end{tabular}




$\begin{array}{ll}\text { PPTEMP } & \text { Coolant pumping power }\left(\mathrm{WW}_{\mathrm{e}}\right) \text {. } \\ \text { PSGMAX } & \text { Maximum size of the steam generators }\left(W W_{t}\right) \text {. } \\ \text { PTGMAX } & \text { Maximum turbine-generator unit size }\left(\mathrm{WN}_{\mathrm{e}}\right) \text {. } \\ \text { OELEC } & \text { Gross electric power }\left(M \mathrm{H}_{e}\right) . \\ \text { SUMT } & \text { Total capital costs }(M \mathrm{~s}) . \\ \text { TUNL } & \text { Length of the tunnels }(\mathrm{m}) . \\ \text { WPC } & \text { Primary-coolant flow rate }(\mathrm{kg} / \mathrm{s}) . \\ \text { WSC } & \text { Secondary-coolant flow rate }(\mathrm{kg} / \mathrm{s}) .\end{array}$

COMNON / PLANTI /

ADCBM Direct cost of the blanket (M\$).

ADCEXR Direct cost of the tritium extraction system (MS).

ADCFAT Direct cost of one target factory (M\$).

ADCRV Direct cost of the driver (M\$).

ADCTRK Direct cost of target/beam tracking, alignment, and delivery $(T, D, A)$ systems for one chamber $(M S)$.

ADCWAL Direct cost of the chamber first wall (HS).

AOCWAL Operating cost of the chamber first wall (M\$).

ATOCBM Operating cost of one reactor blanket (H\$).

BFPSRT Total plant fusion power passed to the blanket coolant systems (neutrons) $\left(\mathrm{HH}_{t}\right)$.

FLOOP Fraction of total coolant outside reactor.

FPWRPT Total plant fusion power $\left(\boldsymbol{H W}_{t}\right)$.

ICTRCK $\quad T, D, A$ system costing switch:

$D$ add cost of $T, D, A$ system for each chamber

1 add cost of $T, D, A$ for number of chambers minus number of drivers

NADD Number of additional T,D,A systems beyond those costed with the drivers.

RRPLT Total plant shot-repetition rate (Hz). 
TCYPC Total coolant volume per chamber $\left(\mathrm{m}^{3}\right)$.

TCVPP Total plant primary coola. $+\left(\mathrm{m}^{3}\right)$.

TINV Total tritium inventory in plant (g).

TINVFC Total tritium inventory in target factories ( $g$ ).

TPYPP Targets shot per year per plant.

COMAN / PLANT2 /

FWPWRT Total plant fusion power deposited in first-wall coolant systems $\left(N w_{t}\right)$.

TDCBM Direct costs of all reactor blankets (M\$).

TDP Total electrical input power for drivers $\left(M H_{e}\right)$.

TTOCBM Operating costs of all blankets (M\$/yr).

\section{CONON / PLANT3 /}

DPPD Input power to driver per driver system $\left(M W_{e}\right)$.

\section{COMHON / PLANTS I}

NXTRAC Number of required tritium extractor units.

SSIT Steady-state tritium inventory in total plant $(g)$.

\section{COMNON / PLANT5 /}

TDCDRI Adjusted direct cost of all drivers (M\$).

TOCEXT Total direct cost of the molten-salt extraction units (M\$).

TDCFAC Total direct cost of all target factories (M\$).

TOCTRC Total direct cost of all T,D,A systems (M\$).

TOCWAL Total direct cost of all first walls (M\$).

TOCWAL Total operating costs of all first walls (M\$).

\section{CONWON / PLANTG /}

TPWRBO Total racial-blanket power per chamber $\left(M H_{t}\right)$. 
TPWRBT Total axial-blanket power per chamber $\left(H W_{t}\right\rangle$.

TTPWR Total blanket power per chamber $\left(M_{t}\right)$.

TVCB Total coolant volume per blanket $\left(\mathrm{m}^{3}\right)$.

\section{COMinON / PLHT /}

TDCPCA Subtotal of adjusted plant costs per chamber (MS).

TDCPLN Subtotal of adjusted plant direct costs (MS).

TOCCAV Subtotal of plant operating costs (M\$).

TOCPCA Subtotal of plant operating costs pei chamber (H\$).

TOTALC Total plant thermal power in ak!al blankets $\left(M W_{t}\right)$.

TOTALP Total plant thermal power in radlal blankets $\left(M H_{t}\right)$.

TTPHRO Total plant power in radial blankets $\left(W_{t}\right)$.

TTPWRT Total plant power in axial blankets $\left(\right.$ Nin $\left._{t}\right)$.

TTTPRH Total plant power in blankets $\left(\boldsymbol{H}_{\mathbf{t}}\right)$.

COMnON / PLTCAS /

CTOT Total reactor piant equipment cost for Account 22 (M\$).

\section{COMION / PONBAL /}

FPOWER Fusion power por thamber $\left(M_{t}\right)$.

RPRATE Shot repetition rate per chamber (Hz).

TYIELD Target yield (MJ).

\section{COMNON / RIHF /}

NYEAR Current year of calculation.

RINF75 Inflation rate for calendar year 1975.

RINF76 Inflation rate for calendar year 1976.

RINF77 Inflation rate for calendar year 1977.

RINF78 Inflation rate for calendar year 1978. 


$\begin{array}{ll}\text { RINF79 } & \text { Inflation rate for calendar year } 1979 . \\ \text { RINF80 } & \text { Inflation rate for calendar year } 1980 . \\ \text { RINF81 } & \text { Inflation rate for calendar year } 1981 . \\ \text { RINF82 } & \text { Inflation rate for calendar year } 1982 . \\ \text { RINF83 } & \text { Inflation rate for calendar year } 1983 . \\ \text { RINF84 } & \text { Inflation rate for calendar year } 1984 . \\ \text { RINF85 } & \text { Inflation rate for calendar year } 1985 .\end{array}$

\section{COMWN / STUFF /}

CFACTR Plant capactity factor.

CRADUS Chamber first-wall radius $\left(\pi_{i}\right)$.

DTWALL Steady-state temperature difference across wall (K).

ICAVIT Chamber designator:

1 graphite/stainless steel

2 stainless steel

3 niobium/stainless steel

4 drywall

5 HYLIFE

6 HIBALL

7 EAGLE

9 Cascade

NCAVIT Number of chambers per plant.

NDRIVE Number of drivers per plant.

PUMPPH Jet-array pumping power $\left(\mathrm{MH}_{\mathrm{e}}\right)$.

TTREL Adjusted tritiun-breeding ratio.

TVCFW First-wall coolant volume $\left(\mathrm{m}^{3}\right)$.

VOLHD Lithium volume in head $\left(\mathrm{m}^{3}\right)$.

VOLPIP Lithium volume in piping $\left(\mathrm{m}^{3}\right)$.

\section{COMYN / TARI /}

ETA Switch for the target gain curve:

-2 advanced concepts, laser driver

-1 lower curve for current designs, laser driver

0 upper curve for current designs, laser driver

$0.05,0.01,0.02,0.04 \mathrm{r}^{3 / 4_{R}}$ value for heavy-ion-beam driver 


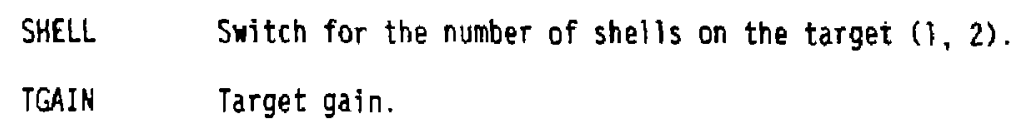

\section{COWON / TARFAC /}

DCFACO Reference cost of a target factory (H\$).

DCFACI Target-factory scaling factor.

DCFAC2 Target-factory scaling factor.

OCFAC3 Target-factory scaling factor.

EPSTGI Target-factory scaling exponent.

EPSTG2 Target-factory scaling exponent.

EPSTG3 Target-factory scaling exponent.

RRFCT Target-factory production rate $(\mathrm{Hz})$.

RRFCTO Reference target-factory production rate (Hz).

TAUFAC Inventory of tritium-fllled targets in factory production process (full power days).

TPYFCT Number of targets per year per factory $\left(y r^{-1}\right)$.

TYIELO Reference target yield (MJ)

\section{COMON / TARGET I}

DCFACT Adjusted airect cost of all target factorles (KS).

GTTGT Tritium inventory in target $(g)$.

INVFCT Tritium inventory in process at a target factory $(g)$.

NTGTFC Number of target factorles per plant.

\section{CONON / TEHER /}

ORP The increment in repetition rate when solving for several repetition-rate situations $(\mathrm{Hz})$.

DTE The increment in driver energy when solving for net power (MJ).

DTEO The initial increment in driver energy when converging on net power (MJ). 
A flag set to 1 when an iteration to find net power is wanted.

NUN An tnternal counter to count the number of times through the loop.

NUMM A flag set to the first time through the loop, thereafter NUMH equals 1 .

PEERR The allowable relative error when converging on net power.

PEFLAG The desired net power of the plant $\left(M W_{e}\right)$.

RPFLAG The maximum allowed repetition rate $(\mathrm{Hz})$.

RPD The initial repetition rate $(\mathrm{Hz})$.

TEFLAG The maximum allowed driver energy ( $M J)$.

TENERG Driver energy incident on target (MJ).

TENERO The initial driver energy when converging on net power (MJ).

\section{COMHOH / TEXTR1 /}

ASSAYG GLi assay in liquid lithium.

CAPEX Capacity of each extractor unit $\left(\mathrm{cm}^{3} / \mathrm{s}\right)$.

DVEX Volumetric distribution of tritium between the lithium and the salt.

EPSEX Efficiency of tritium recovery from the salt.

ETAEX Efficiency factor that accounts for nonequilibrium tritium distribution during contacting.

ETAREM Lumped tritium extraction efficiency.

ILIINV Lithium inventory designator:

1 - first wall + radial blanket + axial blanket

2 - first wall + radial blanket

3 - first wall + axial blanket

4 = radial blanket + axlal blanket

5 = first wall

6 - radial blanket

$7=$ axial blanket

8 = input by user

ITICAL Tritium inventory calculation designator:

1 calculate TRCONC from input SSIT

2 calculate SSIT from input TRCONC

LIFLOW Lithium flow rate to tritium extraction process $\left(\mathrm{cm}^{3} / \mathrm{s}\right)$. 
PRODTR Total tritium source to liquid-metal curtain $(\mathrm{g} / \mathrm{s})$.

PHREX Power required by each extractor unit $\left(M_{e}\right)$.

SSID Total-plant steady-state deuterium inventory in lithium ( $g$ ).

SSIh Total-plant steady-state hydrogen inventory in lithium $(g)$.

TLIINV Lithium inventory in total plant $(g)$.

TRCONC Tritium concentration in liquid lithium (appm).

XFRAC Fraction of lithium inventory processed per unit time $(\mathrm{Hz})$.

\section{CONHON / TEXTR2 /}

LIINV Lithium inventory per chamber $(g)$, only when ILIINV equals 8 .

PXTRAC Total power required by all extractors (Mine).

COHON / TEXTR3 /

VCBO Total coolant yolume in radial blanket $\left(\mathrm{m}^{3}\right)$.

VCBT Axial-blanket coolant volume $\left(\mathrm{m}^{3}\right)$.

\section{COMOH / TRITI /}

ALPHEL Fraction of hellum taken up by liquid lithium inside the chamber.

ALPHYL Fraction of unburned hydrogen gas taken up by liquid lithium inside the chamber.

FBURN Fraction of deuterium and tritium burned per shot.

GOBN Deuterium burned per shot $(g)$.

GDBTGF Deuterium burn rate per target factory $(\mathrm{g} / \mathrm{s})$.

GDFTGF Deuterlum fiow rate per target factory $(\mathrm{g} / \mathrm{s})$.

GDTGT Deuterium charge in the target $(g)$.

GDUBL Unburned deuterium source to liquid-metal curtain ( $g / s)$.

GDUBV Unburned deuterium to vacuum system per shot $(\mathrm{g})$.

GHBN Amount of hydrogen burned per shot $(g)$.

GHBTGF HyJrogen burn rate per target factory $(\mathrm{g} / \mathrm{s})$. 


\begin{tabular}{|c|c|}
\hline GHEPR & Hellum debris produced per shot $(g)$. \\
\hline GHEPRL & Helium debris to liquid-ilthium system per shot $(g)$. \\
\hline GHEPRV & Hellum debris to vacuum systems per shot $(g)$. \\
\hline GHFTGF & Hydrogen flow rate per target factory $(g / s)$. \\
\hline GHTGT & Tritium charge in target $(g)$. \\
\hline GHUBL & Unburned hydrogen source to liquid-metal curtain $(\mathrm{g} / \mathrm{s})$. \\
\hline GHUBV & Unburned hydrogen to vacuum system per shot $(g)$. \\
\hline GPDTGT & Deuterium flow rates per chamber in targets $(\mathrm{g} / \mathrm{s})$. \\
\hline GPOUBL & Deuterium flow to liquid-metal curtain per chamber $(\mathrm{g} / \mathrm{s})$. \\
\hline GPOUBV & Deuterium flow to vacuum per chamber $(\mathrm{g} / \mathrm{s})$. \\
\hline GPHBN & Hydrogen burn rate per chamber $(g / s)$. \\
\hline GPHEPL & Helium flow to liquid-lithium system per chamber $(\mathrm{g} / \mathrm{s})$. \\
\hline GPHEPR & Helium production rate per chamber $(\mathrm{g} / \mathrm{s})$. \\
\hline GPHEPV & Helium flow to vacuum system per chamber $(\mathrm{g} / \mathrm{s})$. \\
\hline GPHTGT & Hydrogen flow rates per chamber in targets $(\mathrm{g} / \mathrm{s})$. \\
\hline GPHUBL & Hydrogen flow to liquid-metal curtain per chamber $(\mathrm{g} / \mathrm{s})$. \\
\hline GPHUBV & Hydrogen fion to vacuum per chamber $(\mathrm{g} / \mathrm{s})$. \\
\hline GPSDBN & Deuterium burn rate per chamber $(g / s)$. \\
\hline GPTBN & Tritium burn rate per chamber $(g / s)$. \\
\hline GPTơR & Tritium breeding rate per chamber $(g / s)$. \\
\hline GPTTGT & Tritium flow rate per chamber in targets $(\mathrm{g} / \mathrm{s})$. \\
\hline GPTUBL & Tritium flow to liquid-metal curtain per chamber $(\mathrm{g} / \mathrm{s})$. \\
\hline GPJUBV & otal tritium-debris flow to vacuum $(\mathrm{g} / \mathrm{s})$ \\
\hline GSDBNP & Deuterium burn rate in tota! plant $(\mathrm{g} / \mathrm{s})$. \\
\hline GSDTGT & Deuterium flow rate in target in total plant $(\mathrm{g} / \mathrm{s})$. \\
\hline GSOUBV & Unburned deuterium flow to vacuum system per chamber $(\mathrm{g} / \mathrm{s})$. \\
\hline GSHBNP & Hydrogen burn rate in total plant $(g / s)$. \\
\hline
\end{tabular}


GSHTGT Hydrogen flow rate in target in total plant $(\mathrm{g} / \mathrm{s})$.

GSHUBL Hydrogen flow to lithium in total plant $(\mathrm{g} / \mathrm{s})$.

GSHUBV Total hydrogen debris flow to yacuum $(g / s)$.

GSTBNP Tritium burn rate in total plant $(\mathrm{g} / \mathrm{s})$.

GSTTGT Tritium flow rate rate in targets in total plant $(g / s)$.

GSTUBV Unburned tritium flow to vacuum system per chamber $(g / s)$.

GTBN Tritfum burned per shot $(g)$.

GTBR Tritium bred per shot $(g)$.

GTBTGT Tritium burn rate per target factory $(\mathrm{g} / \mathrm{s})$.

GTFTGT Tritium flow rate per target factory $(g / s)$.

GTUBL Unburned tritium to liquid-lithium system per shot $(g)$.

GTUBV Unburned tritium to vacuum system per shot $(g)$.

MOLEBN Moles of deuterium and tritium burned per shot. 


\section{INPUT FILE}

There is one input file, unit 5 . This file contains both NAMELIST and formatted data. The NAMELIST variables are listed in this section with their default values in parenthesis. The formatted variables are read in after the NAMELIST variables and are described at the end of this section. A default value of zero usually indicates that the value is internally calculated.

\section{NAMELIST Input}

\section{NAMELIST / ACCHT /}

CLEVI Interim replacement cost fraction (0.01).

CONDOL Switch to convert to constant-dollar fixed-charge rate if CONDOL equals 1 (1).

CONIIM Construction time ( $8 \mathrm{yr})$.

ERATE Escalation rate (6\%).

FCCOMS Fraction of capital from common stock (0.38).

FCDEP Fraction of capital from debt (0.5).

FCPEFS Fraction of capital from preferred stock (0.12).

GINF General inflation factor (6\%).

NUNIT Number of units per piant (1).

NYEAR Current year of calculation (1985).

PLF Power plant life (30 yr).

PTAXR Annual property tax rate (0. 02$)$.

RINF75 Inflation rate for calendar year $1975\left(9.3 \times 10^{-2}\right)$.

RINF76 Inflation rate for calendar year $1976\left(5.2 \times 10^{-2}\right)$.

RINF77 Inflation rate for calendar year $1977\left(5.9 \times 10^{-2}\right)$.

RINF78 Inflation rate for calendar year $1978\left(7.4 \times 10^{-2}\right)$.

RINF79 Inflation rate for calendar year $1979\left(8.6 \times 10^{-2}\right)$.

RINF80 Inflation rate for calendar year $1980\left(9.3 \times 10^{-2}\right)$.

RINF81 Inflation rate for calendar year $1981(9.4 \times 10-2)$. 


$\begin{array}{ll}\text { RINF82 } & \text { Inflation rate for calendar year } 1982\left(6.3 \times 10^{-2}\right) \text {. } \\ \text { RINF83 } & \text { Inflation rate for calendar year } 1983\left(3.8 \times 10^{-2}\right) \text {. } \\ \text { RINF84 } & \text { Inflation rate for calendar year } 1984\left(3.7 \times 10^{-2}\right) \text {. } \\ \text { RINF85 } & \text { Inflation rate for calendar year } 1985\left(3.0 \times 10^{-2}\right) \text {. } \\ \text { RIODEP } & \text { Interest rate on debt (10\%). } \\ \text { RRCOMS } & \text { Rate of return on common stock (14\%). } \\ \text { RRPEFS } & \text { Rate of return on preferred stock (9\%). } \\ \text { TAXR } & \text { Effective income tax rate }(0.48) .\end{array}$

\section{NAMELIST / CBANDS /}

ALPSAR Maximum fraction of sacrificial liner allowed to ablate per shot $(0.02)$.

Cl First coefficient for temperature calculation $\left(0 \mathrm{~K} \cdot \mathrm{m}^{2} .5\right)$.

C2 Second coefficient for temperature calculation $\left(0 \mathrm{~K} \cdot \mathrm{m}^{2}, 5\right)$.

C3 First coefficient for radius calculation $\left(0 \mathrm{~m} \cdot \mathrm{K}^{0.4}\right)$.

C4 Second coefficient for radius calculation $\left(0 \mathrm{~m} \cdot \mathrm{k}^{0.4}\right)$.

C5 Hormalized constant for first HLOSS( $r)$ equation $(\theta \mu \mathrm{m})$.

C6 Exponentiation constant for first WLOSS( $r)$ equation $\left(0 \mathrm{~m}^{2}\right)$.

C7 Radius at which calculation switches from first to second HLOSS $(r)(0)$.

C8 Normalization constant for second $\operatorname{WLOSS}(r)$ equation $(0 \mu m)$.

C9 Exponentiation constant for second HLOSS( $r)$ equation $\left(8 \mathrm{~m}^{-1}\right)$.

c10 Wall loss at which calculation switch from second to first $r$ (WLOSS) (0).

CP Material constant normalized to reference design for temperature rise of sacrificial liner for each pulse $\left(0 \mathrm{~K} \cdot \mathrm{m}^{2} .5 / \mathrm{MJ}\right)$.

CX2 First-wall structure-thickness normallzed constant (D $m \cdot m \cdot m / M J)$.

DAGO Assembly gap between the first wall and the radial blanket (O) cm). 

$(\theta \mathrm{Cm})$.

FLOOP Fraction of total coolant outside reactor $(\theta)$.

FLUFW Fluence $14 \mathrm{mit}$ for neutron damage to first wall $\left(6 \mathrm{MW}-\mathrm{yr} / \mathrm{m}^{2}\right)$.

FLUSTO Fluence limit for neutron damage to radial blanket

$\left(12 \mathrm{MH} \cdot \mathrm{yr} / \mathrm{m}^{2}\right)$.

FLUSTT Fluence limit fol neutron damage to axial blanket $\left(12 \mathrm{~m} / \mathrm{yr} / \mathrm{m}^{2}\right)$.

FRECON Fraction of ablated materials uniformly recondensed ( $\theta$ ).

FSHORT Fraction of fusion energy absorbed on the front surface of the first wall (0.32).

HDRAII Height to diameter ratio for ISHAPE equals 2 (1).

ICAVIT Chamber designator (5):

I graphite/stainless steel

2 stainless steel

3 nlobium/stainless steel

4 drywall

5 HYLIFE

6 HIBALL

7 EAGLE

9 Cascade

ISHAPE Switich for ICF chamber shape (2):

I sphere

2 cylinder

IHDSGN Switch for first-wall-structure thickness (2):

1 fixed

2 calculated

KI Thermal conductivity of sacrificial liner $(0 \mathrm{MH} / \mathrm{mm} \bullet \mathrm{K})$.

K2 Thermal conductivity of first-wall structure $(0 \mathrm{MH} / \mathrm{mm} \circ \mathrm{K})$.

MCOOLO Material number for radial-blanket coolant (1).

MCOOLT Material number for axial-blanket coolant (1).

MINRAD Minimum acceptable chamber radius $(2 \mathrm{~m})$.

MSTROI Material number for radial-blanket structure: component $1(0)$.

MSTRO2 Material number for radial-blanket structure: component $2(\theta)$.

MSTR03 Material number for radial-blanket structure: comporient $3(\emptyset)$.

MSTRO4 Material number for radial-blanket structure: component $4(\theta)$. 


\begin{tabular}{|c|c|}
\hline MSTRT1 & Material number for axial-blanket structure: component 1 (b). \\
\hline MSTRT2 & Material number for axial-blanket structure: component $2(0)$. \\
\hline MSTRT3 & Material number for axial-blanket structure: component $3(b)$. \\
\hline MSTRT4 & Material number for axial-blanket structure: component $4(0)$. \\
\hline NCAVIT & Number of chambers per plant (1). \\
\hline NYRBNK & Year in which blanket materials costs originated (1980). \\
\hline NYRDCA & Year in which chamber materials costs originated (1977). \\
\hline RHOWI & Sacrificial liner density $\left(0 \mathrm{~g} / \mathrm{cm}^{3}\right)$. \\
\hline RHOW2 & First-wall-structure density $\left(0 \mathrm{~g} / \mathrm{cm}^{3}\right)$. \\
\hline STRLFO & Desired radial-blanket-structure lifetime for neutron damage (4). \\
\hline STRLFT & Desired axial-blanket-structure lifetime for neutron damage (4). \\
\hline TO & $\begin{array}{l}\text { Maximum temperature of outside of first wall for boundary } \\
\text { condition for ablation calculation; usually the first-wall } \\
\text { coolant temperature }\left(400^{\circ} \mathrm{C}\right) \text {. }\end{array}$ \\
\hline THSACR & Thickness of sacrificial ablation material $(10 \mathrm{~mm})$. \\
\hline TIRRDO & Radial-blanket irradiation time ( full power years). \\
\hline TIRRDT & Axial-blanket irradiation time ( 0 full power years). \\
\hline TO & $\begin{array}{l}\text { Tritium atoms bred per neutron in radial blanket at } 100 \% \\
\text { solid angle }(0) \text {. }\end{array}$ \\
\hline $\mathrm{TT}$ & $\begin{array}{l}\text { Tritium atoms bred per neutron in axial blanket at } 100 \% \text { solid } \\
\text { angle }(\theta) \text {. }\end{array}$ \\
\hline VFFHC & First-wall coolant volume fraction $(\theta)$ \\
\hline VFFHS & Structural volume fraction of first vall ( 1 ). \\
\hline WCSTI & Unit cost for fabricated sacrificlal liner $(0 \$ / \mathrm{kg})$. \\
\hline HCST2 & Unit cost for fabricated first wall $(0 \$ / \mathrm{kg})$. \\
\hline WLIFE & $\begin{array}{l}\text { Desired first-wall lifetime at } 160 \mathrm{z} \text { capacity factor for } \\
\text { ablation and neutrons ( } 1 \mathrm{yr} \text { ). }\end{array}$ \\
\hline$\times 1$ & Beginning of cycle thickness of sacrificial liner (B mm). \\
\hline$\times 2$ & $\begin{array}{l}\text { Equivalent solid thickness of first-wall structurai material } \\
(0 \mathrm{~mm}) \text {. }\end{array}$ \\
\hline
\end{tabular}




\section{NAMELIST / DSYST /}

ANOT KrF-driver energy-scaling exponent ( $(0.74)$.

BNOT Constant used to determine KrF-driver cost scaling with pulse rate $\left(2.4 \times 10^{-2}\right)$.

CNOT KrF-driver reference cost (150 M\$).

DCHIBI Heavy-ton-beam cost scaling coefficient (680 M\$).

DCHIB2 Heavy-ion-beam cc:t scaling exponent (0.4).

DCLIBI Light-ion-beam cost scaling coefficient (75 MS).

DCLIB2 Light-ion-beam cost scaling exponent ( 0.8$)$.

DCTRCK Direct cost of a T,D,A sys tem per chamber (20 $\mathrm{M \$}$ ).

DFMAG Distance between first wall and beam exit from final focusing magnet $(3 \mathrm{~m})$.

DFMAG2 Length of final focusing magnet $(10 \mathrm{~m})$.

EDNOT KrF-driver reference energy ( $1 \mathrm{MJ}$ ).

ETAD Driver efficiency ( 0 ).

ETANOT KrF-driver reference efficiency ( $\emptyset .09$ ).

FLUOPT Fusion-power fluence limit for final optics

$\left(0.1 \mathrm{MW} \cdot \mathrm{yr} / \mathrm{m}^{2}\right)$.

FNUHAX Maximum f/number for final optics (30).

HIBEAM Radius of heavy-ion beam leaving final focusing magnet exit $(0 \mathrm{~cm})$.

ICTRCK T,D,A system costing switch $(\theta)$.

IDRIVE Switch for driver type (1):

1 short-wayelength laser

3 heavy-ion beam

4 light-ion beam

NBEAM Number of final beams per chamber (2).

NDRIVE Number of stivers per plant (1).

NYRHIB Year in which heavy-ion-beam cost estimates originated (1983).

NYRLIB Year in which light-ion-beam cost estimates originated (1979). 


\begin{tabular}{|c|c|}
\hline NYRSWL & Year in which laser cost estimates originated (1983). \\
\hline NYRTRC & Year in which $T, D, A$ system costs originated (IgBO). \\
\hline OOL & Optical damage limit $\left(4 \mathrm{~J} / \mathrm{cm}^{2}\right)$. \\
\hline OPTICL & Radius of final optics $(0 \mathrm{~m})$. \\
\hline OPTLIF & Desired lifetime of final optics ( $\mathrm{yr}$. \\
\hline РСHOT & $\begin{array}{l}\text { Constant used to determine the KrF-driver efficiency } \\
\left(1.74 \times 10^{-3}\right) \text {. }\end{array}$ \\
\hline RDNOT & KrF-driver reference pulise rate $(1 \mathrm{~Hz})$. \\
\hline TAU & KrF-driver pulse length ( $10 \mathrm{~ns}$ ). \\
\hline TAUNOT & KrF-driver reference pulse length (10 ns). \\
\hline
\end{tabular}

\section{MAMELIST / FUEL /}

ALPHEL Fraction of helium taken up by liquid lithium inside the chamber (b).

ALPHYL Fraction of unburned hydrogen gas taken up by liquid lithium inside the chamber (6).

ASSAYG GLi assay in liquid lithium $\left(7.5 \times 10^{-2}\right)$.

CAPEX Capacity of each extractor unit $\left(3200 \mathrm{~cm}^{3} / 5\right)$.

DCEXTR Direct cost of an extractor unit of capacity CAPEX (1 M\$).

DCFACD Reference cost of a target factory (100 M\$).

DCFACI Target-factory scaling factor ( 9.333$)$.

DCFAC2 Target-factory scaling factor (0.333).

DCFAC3 Target-factory scaling factor (0.333).

DVEX Volumetric distribution of tritium between the lithium and the salt (2).

EPSEX Efficiency of tritium recovery from the salt (0.9).

EPSTGI Target-factory scaling exponent (1.0).

EPSTG2 Target-factory scaling exponent (0.333).

EPSTG3 Target-factory scaling exponent (0.333). 
ETAEX

Efficiency factor that accounts for nonequilibrium tritium (0.3).

FBURN Fraction of deuterium and tritium burned per shot (0.3).

ILIINV LIthilum inventory designator (1):

1 - first wall + radial blanket + axial blanket

2 - first wall + radial blanket

3 - first wall + axfal blanket

4 = radial blanket + axial blanket

5 - first wall

6. radial blanket

7 = axlal blanket

$B=$ Input by user

ITICAL Tritfum inventory calculation designator (2):

1 calculate TRCONC from input SSIT

2 calculate SSIT from input TRCONC

LIINV Lithium inventory per chamber $(0 \mathrm{~g})$, only when ILIINV equats 8.

NTGTFC Number of target factories per plant (1).

NYREX Year in which extractor cost estimate originated (1980).

NYRTF Year in which the target-factory cost estimates originated (1983).

PWREX Power required by each extractor unit $\left(3.73 \times 10^{-3} \mathrm{NH}_{\mathrm{e}}\right)$.

RRFCTO Reference target factory production rate $(5 \mathrm{~Hz})$.

SSIT Steady-state tritium inventory in liquid curtain in the total plant $(\varphi \mathrm{g})$.

TAUFAC Inventory of tritiun-filled targets in factory production process (2 full power days).

TRCONC Tritlum concentration in liquid lithium (1.0 appm).

TYIEL $\emptyset$ Reference target yield (600 MJ).

MAMELIST / UWIM /

ALPHI Normalized constant for impact stress (b).

ALPH Thermal expansion coefficient $\left(0 \mathrm{~K}^{-1}\right)$.

C Speed of sound in 11 thium $(0 \mathrm{~m} / \mathrm{s})$.

CHI Preexponential for IH scaling (b).

CH2 Exponential for IH scaling ( $\theta$ ). 
The dpa limit constant (1).

F2

The appm helium 1 imit constant (1).

F3

Constant used for maximum impact stress calculations (1).

F4

Constant used for yield stress limit calculations ( 1 .

FIN]

Fractional area coverage at inlet $(0.77)$.

FMIN

Mfnimum It thium fractional midplane coverage $(0.5)$.

GAMY

Grïneisen coefficient (8).

GASOEN

Lithium vapor density $\left(0 \mathrm{~g} / \mathrm{cm}^{3}\right)$.

GNU

Poisson's ratio (0).

IDPA

Damage 1imit desfonator (1):

0 appm is limiting

1 dpa is liniting

IH

Scaling option switch for chamber height (1).

1 scales as the square root of fusion power

2 scales as the square root of target yleld

3 scales as fusion power ralsed to the $\mathrm{CH} 2$

IRW

Scaling option switch for wall radius (1).

1,2 are the same as for IH

3 scales as fusion power raised to the CHA2

RHO

Liquid-lithium density $\left(485 \mathrm{~kg} / \mathrm{m}^{3}\right)$.

SI(3) Impact stress coefficients $(0,0,0)$.

SY(3) Yield stress coefficients $(0,0,0)$.

Liquid-lithium operating temperature $(0 \mathrm{~K})$.

UU

Energy attenuation coefficlent ( $\theta$ ).

WALLC Constant multipller for wall deuterium and tritium (b).

XLAMDA Constant used in calculating the lithium-slug size (c).

YOUNGM Young's modulus (O MPa). 


\section{NAMELIST / TASK /}

CFACTR Plant capacity factor (0.7).

DRP The increment in repetition rate when solving for several repetition rates $(\theta \mathrm{Hz})$.

DTE The increment in driver energy when solving for net power (0 MJ).

ETA

Switch for the target gain curve $(\theta)$ :

-2 advanced concepts, laser driver

- l lower curve for current designs, laser driver

upper curve for current designs, laser driver

$0.05,0.01,0.02,0.04 \mathrm{r}^{3 / 2} \mathrm{R}$ value for heavy-ion-beam driver

FPOWER Fustion power per chamber $\left(0 M w_{t}\right)$.

IACCT Switch to read the ACCNT NAMELISI if IACCT equals 1 (1).

ICBAND Switch to read the CBANDS NAMELIST if ICBAND equals 1 (1).

IDSYST Switch to read the DSYST NAMELIST if IDSYST equals 1 (1).

IFLAG A flag set to 1 when an iteration of find net power is wanted $(0)$.

IFUEL Switch to read the FUEL NAMELIST if IFUEL equals 1 (1).

IPRINT Switch to print NAMELIST parameters if IPRINT is greater than 1 (3).

PEERR The allowable relative error when converging on net power (B).

PEFEAG The desired net power of the plant $\left(0 \mathrm{H}_{\mathrm{e}}\right)$.

RPFLAG The maximum allowed repetition rate $(0 \mathrm{~Hz})$.

RPRATE Shot repetition rate per chamber $(0 \mathrm{~Hz})$,

SHELL Switch for the number of shells on the target (1 or 2) (0).

TEFLAG The maximum allowed driver energy ( $\mathrm{MJ}$ ).

TENERG Driver energy incident on target ( $B$ MJ).

TGAIN Target energy gain ( $(\theta)$.

TYIELD Target yield (O MJ). 
The NAMELIST variables are read in the following sequence after a one line title:

\section{NAMELIST Condition for reading}

\begin{tabular}{ll} 
TASK & always \\
CBANDS & if ICBANOS. eq.1 \\
LMHIN & if ICAVIT. eq.5,6.7 \\
OSYST & if IDSYST. eq.1 \\
FUEL & if IFUEL.eq.1 \\
ACCNT & if IACCT.eq.1 \\
\hline
\end{tabular}

\section{Formatted Input}

After the NAMELIST variables are read, the following formatted input variables are read. These variables are read for all cavity types except Cascade.

\begin{tabular}{ll} 
Variable & Format \\
\hline EMO(L), $L=1,6$ & $6 E 12.5$ \\
MATLO(L), $L=1,6$ & $6 A 12$ \\
VFBSO(L,M), M=1,6, L = 1,6 & $6 E 12.5$ \\
DBO(L), $L=1,6$ & $6 E 12.5$ \\
$\operatorname{UCOBSO}(L, M), M=1,6, L=1,6$ & $6 E 12.5$ \\
EMT(L), $L=1,6$ & $6 E 12.5$ \\
$\operatorname{MATLT}(L), L=1,6$ & $6 A 12$ \\
$\operatorname{VFBST}(L, M), M=1,6, L=1,6$ & $6 E 12.5$ \\
$\operatorname{DBT}(L), L=1,6$ & $6 E 12.5$ \\
$\operatorname{UCOBST}(L, M), M=1,6, L=1,6$ & $6 E 12.5$ \\
DELTC, EXTEMP, PIN, DELPB, PPFR & $5 E 12.5$ \\
PSGMAX, TSUP & $2 E 12.5$ \\
IBCLT, NLOOP & 2112 \\
PTGMAX, FELBOP & $2 E 12.5$
\end{tabular}

For the Cascade chamber, (ICAVIT - 9), there is only one formatted read statement: DELTC, EXTEMP 2 E12.5 


\section{INPUT/OUTPUT (I/O) UNITS}

The SAFIRE code uses five different $1 / 0$ units. These units are listed below with their specific function.

Unit File name Function

No.

$\begin{array}{lll}5 & \text { infile } & \text { All input variables are read from this file } \\ 6 & \text { outfile } & \text { The long version of the output } \\ 7 & \text { shtfill } & \text { The one page version of the output } \\ 8 & \text { flofile } & \text { The NAMELIST reiteration and sequence of routines } \\ 9 & \text { shtfil2 } & \text { The two page version of the short output }\end{array}$

The only non-FORTRAN 77 statement in the SAFIRE code is the NAMELIST statement. The code was not revised to el iminate this statement for two reasons: most mainframe FORTRAN compllers have this option and using NAMELIST greatiy simplifies the input file. 


\section{ACKNONLEOGHENT}

The authors thank Elaine Price of the Technical Information Department for her editorial assistance on this manual. Numerous errors, inconsistencies, and omissions were detected and corrected as a result of her work. We aiso appreciate her suggestions on the organization and layout of this manual. 
APPENDIX A :

EXAMPLE IHPUT AND OUTPUT FILES FOR SAFIRE

Figures A-1 through A-4 are examples of input files for the various reactor types. Figures $A-5$ through $A-7$ list example output files for the HYLIFE reactor, using the input file of Fig. A-1.

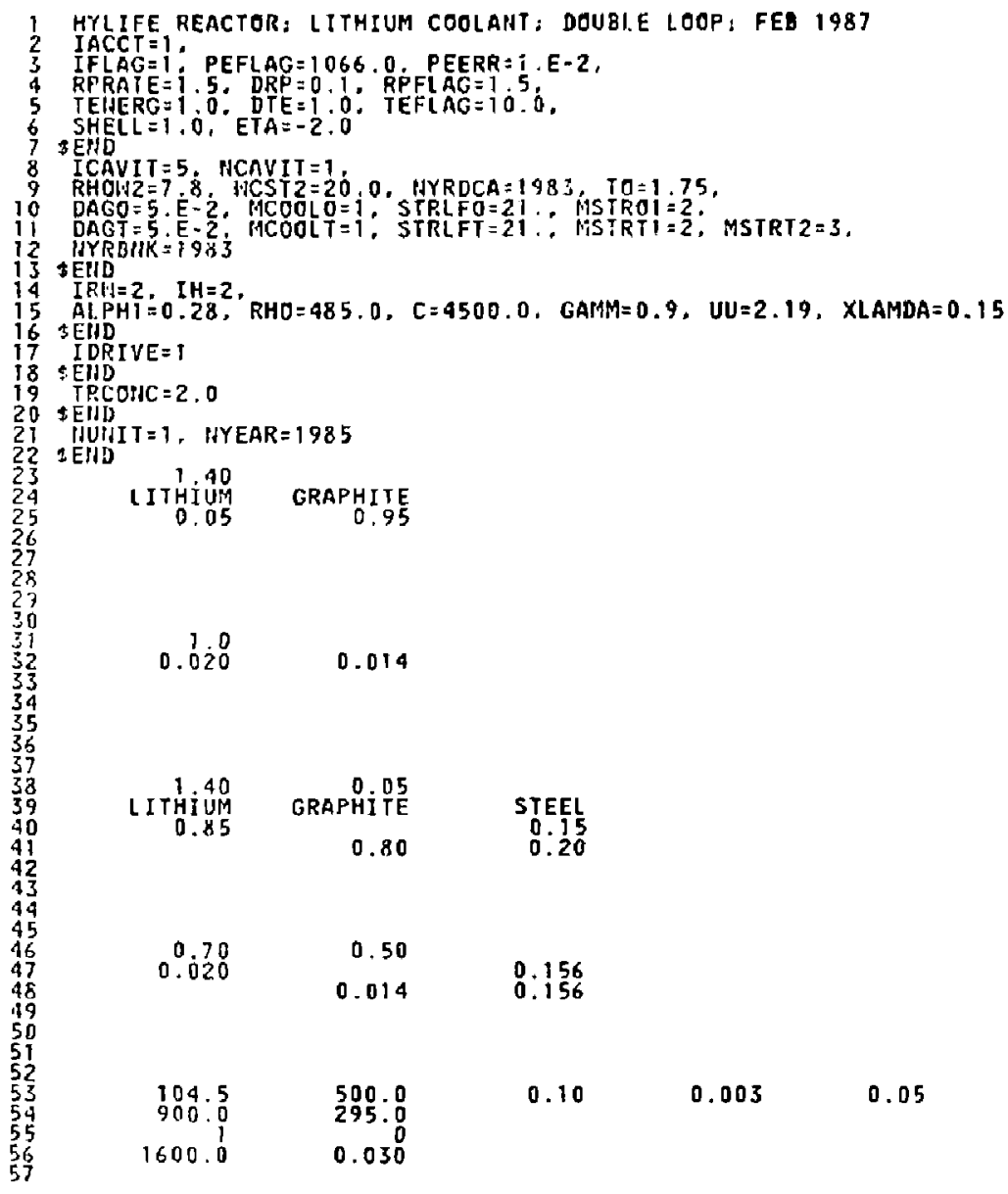

Figure A-1. Input file for the HYLIFE reactor. 


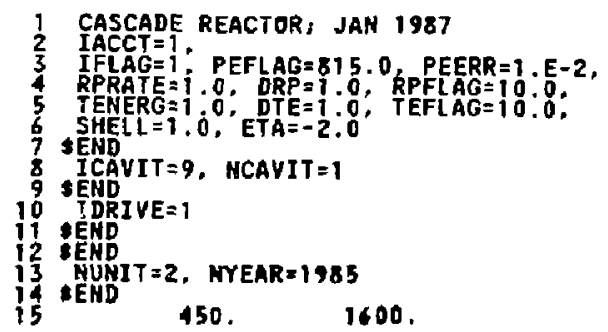

Figure A-2, Input file for the Cascade reactor.

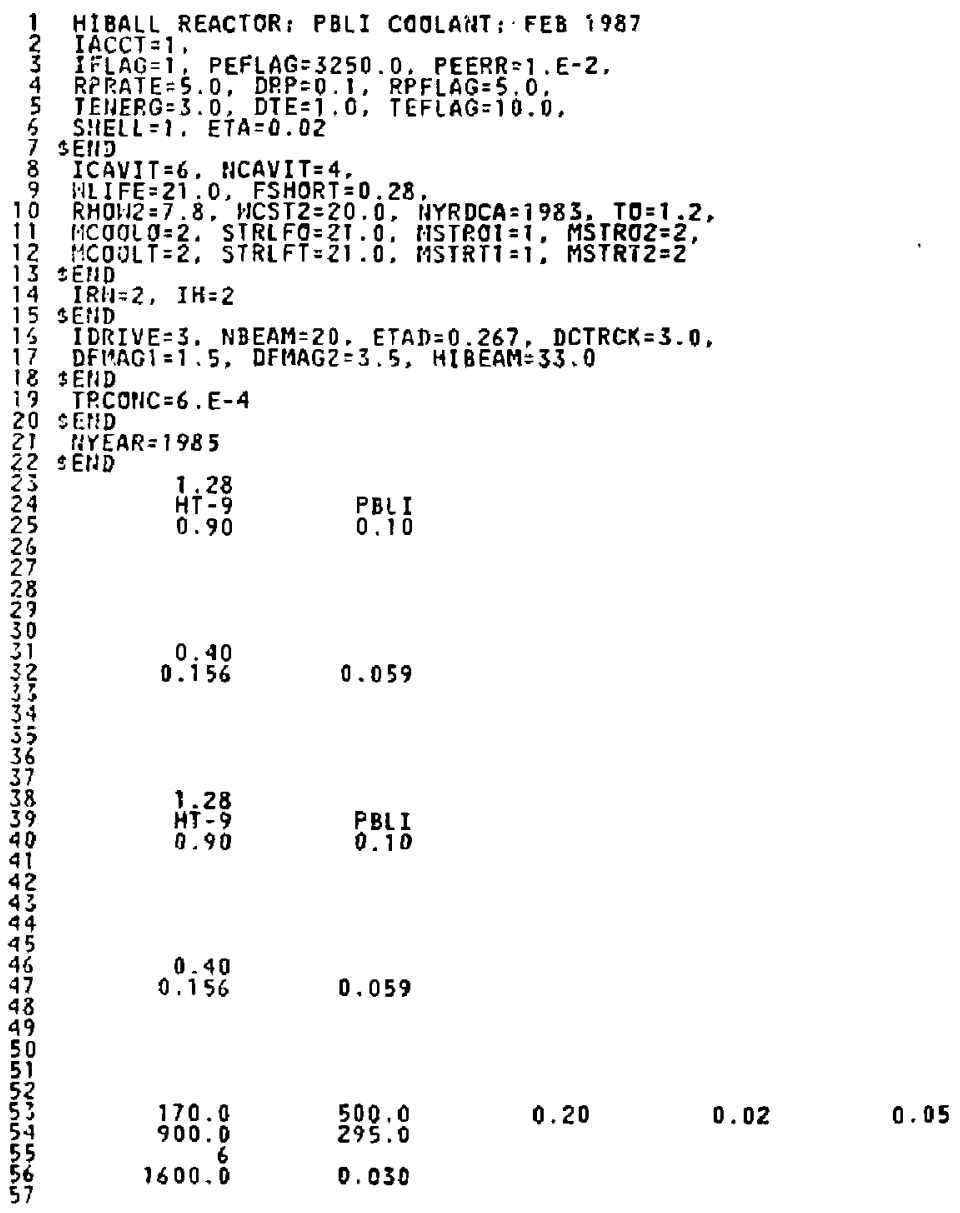

Figure A-3. Input file for the HIBALL reactor. 


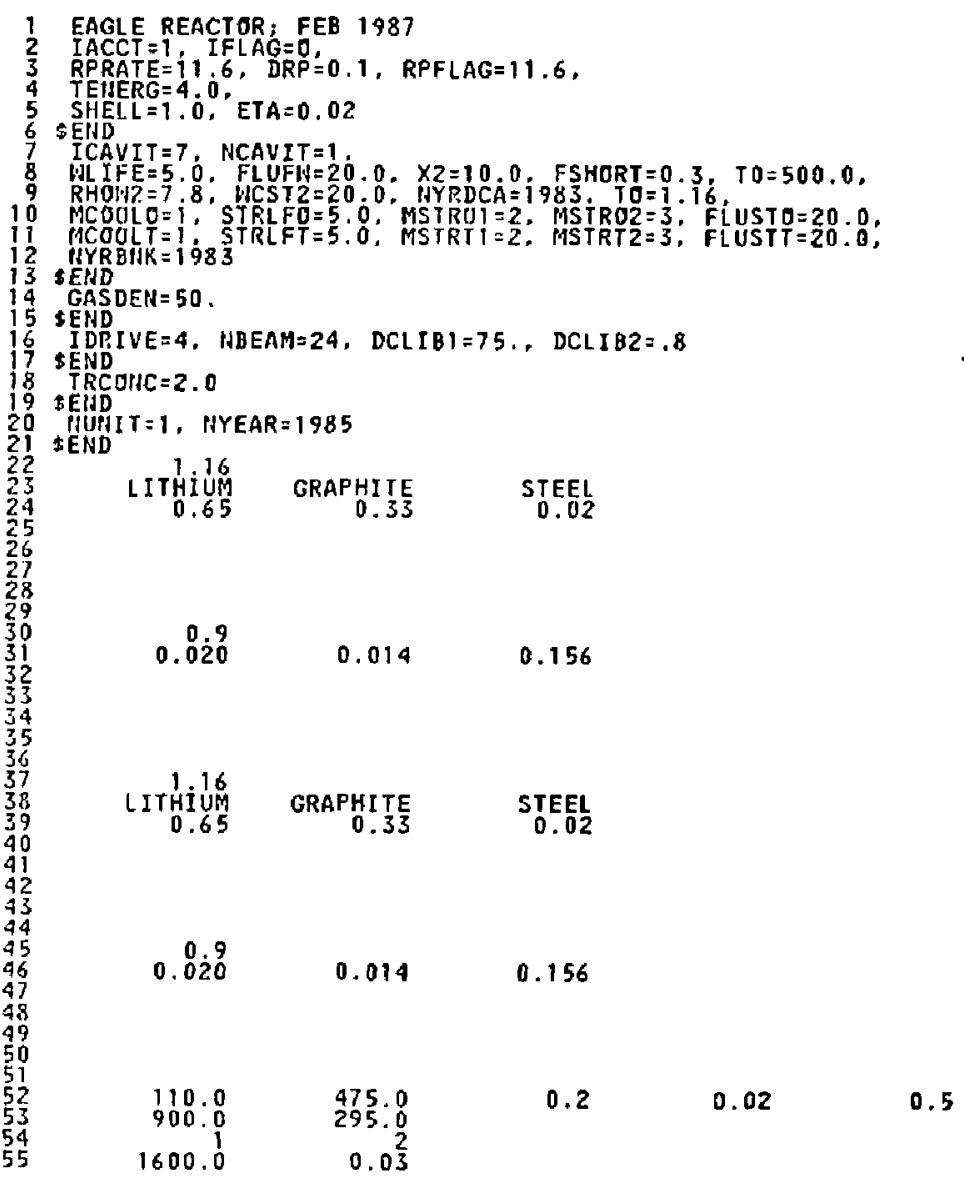

Figure A-4. Input file for the EAGLE reactor. 
THIS FILE CONTAINS THE SHORTENED OUTPUT FROM THE SAFIRE CODE.

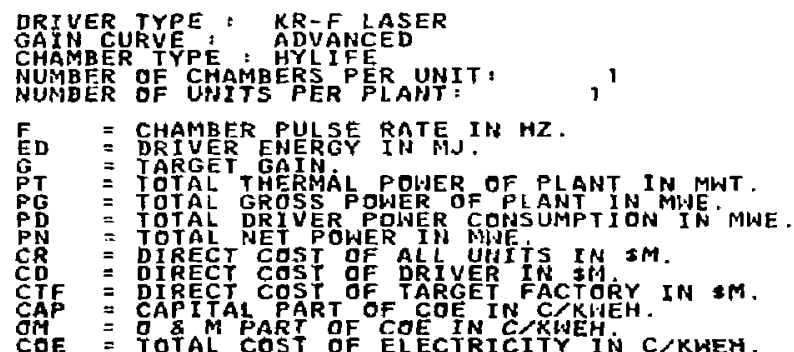

Figure A-5. Output file shtfil1 for the HYLIFE reactor. 
CASE TITLE: HYLIFE REACTOR; LITHIUM COOLANT; DOUBLE LOOP; FEB 1987

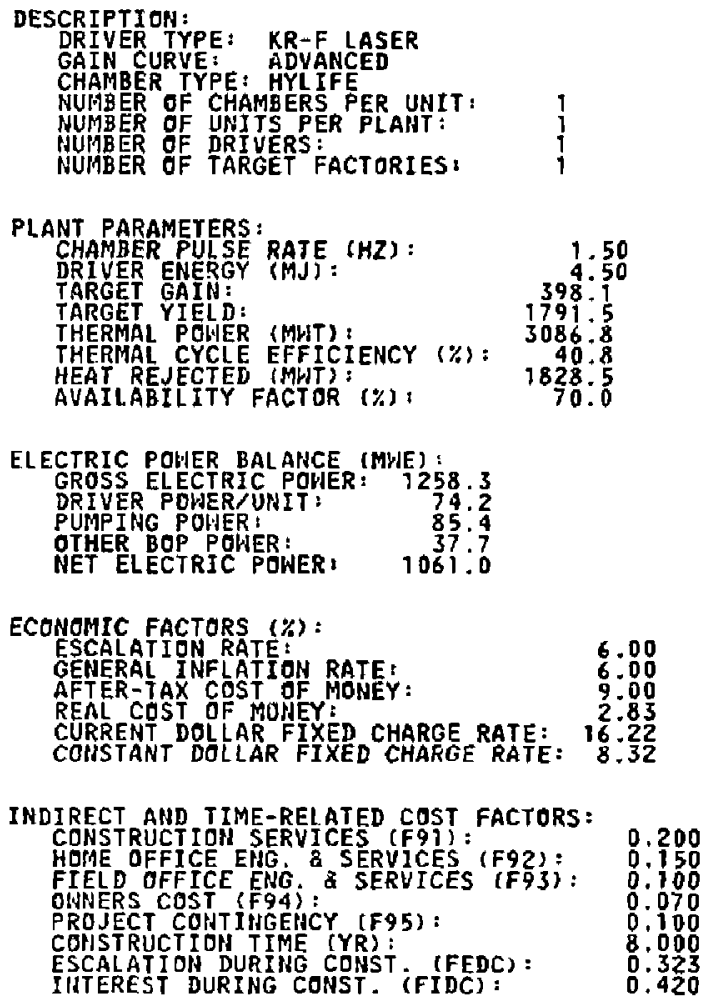

Figure A-6. Output file shtfil2 for the HYLIFE reactor. 
ICF POWER PLANT ECONONIC EVALUATION

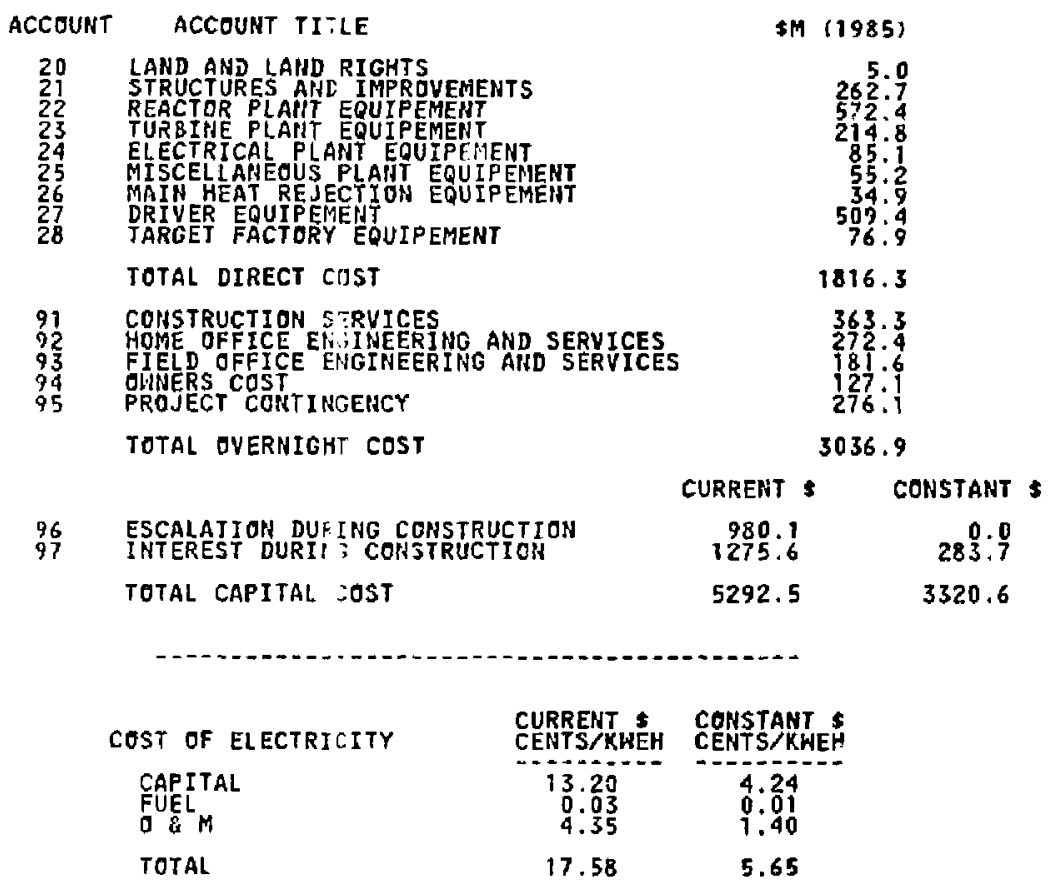

Figure A-6. (Continued.) 
ENTER SAFIRE: ICF SYSTEMS AHALYSIS CODE

THE SAFIRE CODE HAS MANY AUTHORS WHO HAVE CONTRIBUTED DUER THE YEARS. THE MOST RECENT AUTHORS INCLUDE:

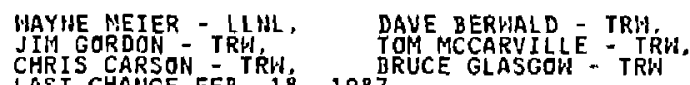
HOTE: - QUANTITIES DESIGHATED BY +++++ INCLUDE AVERAGE
CAPACITY FACTOR INFL UEIICE

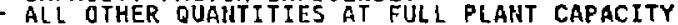
- MUST IIIFO IS FOR THE FIRST UHIT IN THE CASE OF MULTI-UHIT POWER PLAHTS. COST SUAMARY IS FOR TUTAL PLAHT

Figure A-7. Output file outfile for the HYLIFE reactor. 


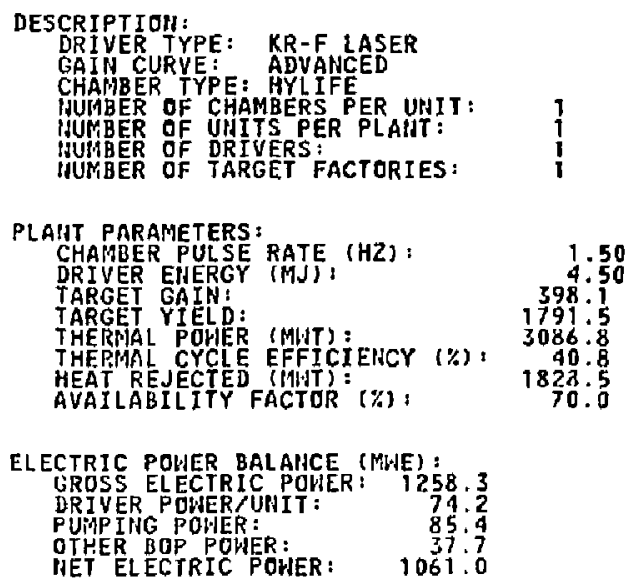

PLAIIT PARANETERS :

CHAMBER PULSE RATE (HZ):

DRIVER ENERGY (MJ):

TARGET GAIN:

TARGET YIELD:

THERPIAL POHER (MVT) :

THEPMAL CYCLE EFFICIENCY $(\%)$

KEAT REJECTED (MIIT):

AVAILABILITY FACTOR (\%):

1.50
4.50
398.1
1791.5
3086.8
97.8
1828.5
70.0

ELECTRIC POUER BALAHCE (MWE) :

GROSS ELECIRIC POWER: 1258.3

DRIVER POWER I UNIT :

PUIMPING POWER:

OTHER BOP POWER:

WET ELECTRIC POWER: 106 1 :

KR-F LASER DRIVER PERFORMALCE \& COST INFORMATION:

DRIVER OUTPUT ENERGY $=4.50 \mathrm{MJ}$

DRIVER EFFICIENCY $=0.091$

DRIVER IHPUT ELECTRICAL EHERGY PER SHOT $=49.47 \mathrm{~mJ}$

DRIVER REPETITIÓF RATE = 1.50 SHOTS/SEC

REQUIRED INPUT ELECTRICAL JOWER PER DRIVER= 74.20 MWE

FINAL FOCUSING OPTICS (OR IAAGNET) INFORHATION:

HUMBER OF BEAMS $=2$

OPTICAL DAMAGE LIMIT $=4.00 \mathrm{~J} / \mathrm{CM}$ SQ

RADIUS OF FINAL OPTICS $=423.1 \mathrm{CM}$

DISTALCE OF FINAL OPTICS FROM CHAMBER CENTER $=38.7 \mathrm{M}+++++$

- TO SATISFY THE FOLLOWIUG USER REQUIREMENTS:

- DESIRED FINAL OPTICS LIFETIME = 1,0 YR

OPTICAL SURFACE FLSION HEUTROH DAMAGE LIMIT=0.10 MW YR/M SO

REQUIRED FINAL OPTICS COR FOCUSING MAGNET F NUMBER FOR AGOVE= 4.6
SOLID ANGLE LOSI DUE TO BEAM PENETRATIONS 0.545 OF 12.6 STERADIANS

Figure A-7. (Continued.) 
CHAMBER PERFORMANCE AIID COST INFORMATION:

BASIS: ONE ICF CHAMBER

CHAMBER TYPE: HYLIFE, STEEL WALL

POWER RELATED INFORMATION:

FUSION YIEL'D=1791 5 MJ 32.0 PCT, SHORT RANGE, 68.0 PCT. LOHG RANGE) MICROEXPLOSION REPETITION RATEE

GEOMETRY RELATED INFORMATION:

FIUAL CHAMBER RADIUS $=5.0 \mathrm{M}$

CHAHBER GEOMETRY IS RIGHT CIRCULAR CYLIHDRICAL

HEIGHT/DIALIETER RATIU $=0.8$

CHAHBER AREA $=328.3 \mathrm{M}$ SO

USEFUL SOLID AIULLE FRACTION $=0.957$

CHAHDER VOLUME $=623.9$ M CUBE

COMPUTED EQUIVALEHT FIRST WHAL STRUCTURE THICKNESS $=42.5 \mathrm{MM}$ (SOLID)

TOTAL FIRSI WALL THICKNESS (IMCL COOLAHT AHD VOID) $=42.5 \mathrm{MM}$

TOTAL FIRST WALL COOLAHT VOLUME $=0.515 \mathrm{e}+02$ in CUBE

DESIGN VALUES FOR LIQUID METAL JETS

$\begin{array}{lr}\text { LM BLAIIKET HEAD LOSS } & \\ \text { JET ARRAY EFFECIIUE THICKNESS } & 4.57 \\ \text { IMNER JET RADIUS } & 0.86 \\ \text { MIDPLAIIE PACKIMG FRACTION } & 0.39 \\ \text { JET ARRAY IMPACT STRESS } & 0.56 \\ \text { FIRST WALL THERMAL STRESS } & 160.9 \mathrm{MPA} \\ \text { FIRT } & \end{array}$

JET ARRAY FLOW REQUIREMENTS

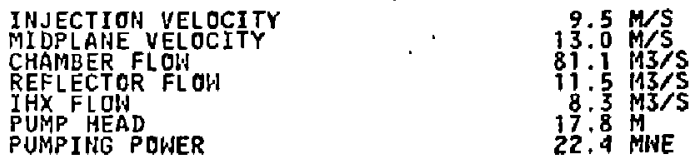

LIQUID METAL VOLUME TALLY

VOLUME IN CHAMBER

VOLUME IN HEAD

VOL UAAE IN PIPIHG

MERGE TO OHE LOOP (IE. THEY ARE COMPATABL

FIRST WALL RAD US SELECTION INFTRMATION:

JET ARRAY EFFECTIYE THICKNESS OF 0.8639 METERS GIVES A 30.00 YEAR LIFE

FIRST WALL FABRICATED MATERIALS COST IHFORMATION:

FIRST WALL DIPECT COST $=0.234 \mathrm{e}+07$ III 1985 DOLLARS

FIRST WALL OPERATIMG COST $=0.780 \mathrm{e}+05$ \$YYR IH 1985 DOLLARS +++4+

Figure A-7. (Continued.) 
BLANKET AND SHIELD PERFORMAHCE AND COST INFORMATION:

BASIS: ONE ICF CHAMEER

GEOMETRY \& MATERIALS COMPOSITION INFORMATION FOR STRUCTURAL COMPOHENTS: RADIAL BLANKET AXIAL BLANKETS

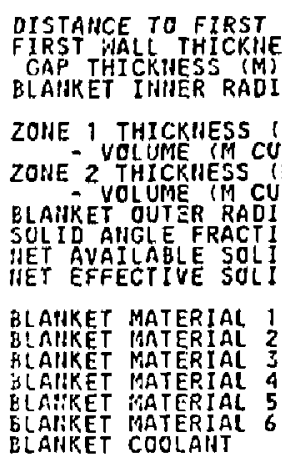

$\begin{array}{ll}4.988 & 3.991 \\ .042 & .042 \\ 5050 & 5050 \\ 5.081 & 4.083\end{array}$

1.000

0.700

$0.280 e+03$

$\dot{0} 09 \mathrm{e}+03$

ZONE 2 THICKIIESS (H) (M)

BLAINE E TUTER RADI ST

JET AVAILABLE SOLID AHGLE FRACTIOH WET EFFECTIVE SULID AIIGLE FRACTIOH

6.081

.625

.957

$0.7820+02$

LITHI UM

5,283 0.957

GRAPHITE

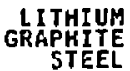

LITHIUH

LITHIUM

BLALIKET MATERIAL VOLUME FRACTIOHS BY ZONE:

RADIAL BLAIJKET

ZCHE I

10.050

2 BLAIIKE! MATERTAL 4

0.950

0.000

0.000

56

AXIAL BLAPKETS

ZOIE

$2^{\text {BLAHKET MATERIAL }} 4$.

0.000

0.000

$1 \quad 0.850$

0.000

0.150

0.000

5

6

2

0.000

0.800

0.200

0.000

$0.000 \quad 0.000$

BLAHKET MATERIAL VOLUMFS (M CUBE) BY ZOHE:

RADIAL BLAIIKET

\begin{tabular}{|c|c|c|c|c|c|c|c|}
\hline zOUE & 1 & $2^{B L A R}$ & JKET & ${ }_{3}^{M A T E R I A L}$ & 4 & & \\
\hline 1 & $0.140 e+02$ & $0.266 e+03$ & D. & 0 . & & 0. & 0 . \\
\hline$A X I A L$ & SLAHKETS & & & & & & \\
\hline ZOHE & 1 & $2^{\text {BLAl. }}$ & IKET & $\underset{3}{\text { MATERIAL }}$ & 4 & & \\
\hline 1 & $0.930 e+02$ & 0 & 0.16 & $69 e+020$ & & 0 . & D. \\
\hline 2 & 0. & $0.625 e+02$ & 0.15 & $56 \mathrm{e}+020$. & & 0 & 0. \\
\hline
\end{tabular}

Figure A-T. (Continued.) 
BLANKET POHER RELATED INFORMATION:

RADIAL BLANKET AXIAL BLANKETS

ZONE 1 FUSION MEUT, ENERGY MULTIPLICATION 1.40 - POHER (MHIT) (W/CM CUBE)

1.40

$13 \frac{1}{8} \cdot 5$

ZONE 2 FUSIOH HEUT ENIERGY MULTIPLICATIOW - POUHER DEIISITY (W/CM CUBE)

- POLER (MHT)

TOTAL FUSIOH REUT. ENERGY MULTIPLICATION

TOTAL POHER (HWT)

TOTAL COOLANT VOLUME (M CUBF)

2300

$0.1400^{5}+02$

0.05

0.1

1.45

$0.9300^{4}+02$

BLALIKET EIIERGY MULTIPLICATION FOR TOTAL CHAMBER $=1.36$

BLAHKET POU.AER FOR TOTAL CHAIIBER $=374$. D MWT

BLALKET CDOLANT VOLUME FOR TOTAL. CHAMBER $=0.107 \mathrm{e}+03 \mathrm{M} \mathrm{CUBE}$

BLAHKET TRITIUM BREEDIHG IHFORMATIOH:

TRIJIUM BREEDING IN LIQUID METAL BLANKET

RADIAL BLAHKET

TRITIUM BREEDING PER FUSION NEUTRON

1.750

ADJUSATED TRITIUM BREEDIHG PER FUSIOH

TRITIUM PRODUCTIUR (KG/YR) $+++++\infty$

1,750

BLANKET MATERIALS COST INFORMATION:

BLANKET MATERIALS COSJ (MILLION $\$$ /M CUBE) BY ZOHE:

RADIAL BLANKET

ZONE 1

2 BLANKET $\underset{3}{\text { MATERIAL }}$

$10.200 \mathrm{e}-01 \quad 0.140 \mathrm{e}-010$.

0 .

4

AXIAL BLAHKETS

ZONE

2 BLAHKET MATERIAL

$10.200 \mathrm{e}-010$.

$0.756 \mathrm{e}+000$.

4

0.

0

20

$0.140 \mathrm{e}-01$

$0.156 \mathrm{e}+000$.

0 o. 0 .

0 . 0 .

TOTAL BLAIKET DIRECT COST $=0.576 \mathrm{e}+08$ IIf 1985 DOLLARS

TOTAL BLANKET OPERATIHG COST $=0.714 e+06$ IN 1985 DOLLARS $+4++4$

Figure A-7. (Continued.) 
PER ICF TARGET FACTORY PERFORMANCE AND COST INFORMATION:

TARGET PRODUCTION RATE $=150$ ICF TARGETS/SEC

TARGEIS PRODUCED PER YEAR $=0,331$ e+08 $+4+++$
TARGET FACTORY DIRECT COST $=0.369 e+08$ DOLLARS

MOLTEN SALT TRITIUH EXTRACTIOH SYSTEM IHFORMATION:

IIOUID METAL INVENT ORY PER UHIT $=0.752 e+09$ GM

TOTAL TRITIUM SOURCE TO LIQ. MET. BLALKET $=0.8320-02 \mathrm{GM} / \mathrm{SEC}$

TRITIUI CONCEPITRATIOH IN LIO. MET. BLAHKET $00.200 \mathrm{O}+01$ APPM

LUMPED EXTRACTIOU EFFICIEUCY OF 0.351 DERIVED FROM

- EFFICIEHICY OF TRITIUN RECOVERY FROIT THE SAL T $=0.900$

- VOLUHETRIC DISTR COEFF BETHEEWLI AHI SALTEZ OOO

HONEOUILI BRIUM TRIT. DISTR. EFFIC. FACTOR=O JOO

REOUIRED PROCESS RATE: 170.2750\$05 OF TOTAL LI PER SEC

ABOVE LI FLOH CORRESPOHDS TO 0.565 E $\div 55$ CM CUBE/SEC

ABOYE REQUIRES I8 EXTRACTOR UHITS OF D.320E+04 CM CUBE/SEC EACH

EACH EXTRACTOR UNIT REQUIRES $0.00373 \mathrm{MWE}$

EXTRACTQR UHIT COST $=0.137 \mathrm{e}+01$ HE

FUSIOH FUEL FLOH AHD IHVEHTORY IHFORMATIOH:

$D-T$ BURN FRACTION $=0,30$

WOLES OF D-T FUEL BURLEO PER SHOT $=0.106 \mathrm{e}-02$

PER SHOT IRFORMATION (AL.L GM)

TRITIUM DEUTERIUM HYDROGEN

AMOUHT BURNED PER SHDT

AMOUHT BRED PER SHOT

CHARGE IH TARGET

UHAURHED DEBRIS TO VACUUM SYSTEMS

PATE IHFORHATION (ALL GM/SEC)

BURN RATE PER CHAMBER

$0.317 \mathrm{e}-02 \quad 0.2 i 1 e^{-02} \quad 0.528 \mathrm{e}-02$

$0.555 \mathrm{e}-02$

$0.106 e-01$ 0.704e-02 0.176e-01

$0.740 \mathrm{e}-020.493 \mathrm{e}-020.123 \mathrm{e}-01$

EREEDILG RATE PER CHAMBER

FLOW RATE III TARGETS PER CHAMBER

DELRIS FLOH TO VACUUM PSR CHAMBER

BURAN RATE PER UIIIT

BREEDIUG RATE PER UHIT

FIOW RATE IH TARGETS PER UHIT

DEBRIS FLOW TO VACUUH PER UNIT

EURN RATE PER TARGET FACTORY

FLOW RATE IH TARGETS PER TARGET FACTORY

$0.475 e-02 \quad 0.317 e-02 \quad 0.792 e-02$

$0.832 \mathrm{e}-02 \mathrm{NA} N \mathrm{NA}$

$0.158 \mathrm{e}-010.106 \mathrm{e}-010.264 \mathrm{e}-0$

0 11 ie-01 $0.740 \mathrm{e}-020.185 \mathrm{e}-01$

$0.475 \mathrm{e}-02 \quad 0.317 \mathrm{e}-02 \quad 0.792 \mathrm{e}-02$

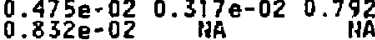

$0.158 e-010.106 e-010.264 e-01$

$0.711 e-070.740 e-02 \quad 0.185 e-01$

$0.475 e-020.317 e-020.792 e-02$

$0.158 \mathrm{e}-010.106 \mathrm{e}-010.264 \mathrm{e}-01$

TRITIUM INVENTORY INFORMATION (ALL GM)

IAVENTORY IN TARGET

INVEPTCRY IN LIQ MET. BLAIIKET

IIVELTORY IN A TARGEY FACTORY

INVENTORY IN ALL TARGET FACTORIES

IHVEHTORY IN ALL TRITIUM BREEDIHG SYST.

TOTAL TRITIUM INUEMTORY III PLAIT

$1.056 \mathrm{e}-02$

$6.513 \mathrm{e}+02$

$2.738 \mathrm{e}+03$

$2.738 \mathrm{e}+03$

$6.513 e+02$

MELIUM (DEBRIS) GEHERATIOH IUFORMATIOH

GENERATIOH PER SHOT $=0.423 \mathrm{e}-02 \mathrm{GH}$

AMOUNT PASSED TO YACUUM SYSTEM PER SHOT $=0.423 \mathrm{e}-02 \mathrm{GM}$

HELIUM GEHERAT IOH RATE PER CHAMBER $=0.634 \mathrm{e}-02 \mathrm{GM} / \mathrm{SEC}$

FLEW TO VACUUM PER CHAMBER $=0.634 \mathrm{e}-02$ GM $\mathrm{SEC}$

Figure A-7. (Continued.) 


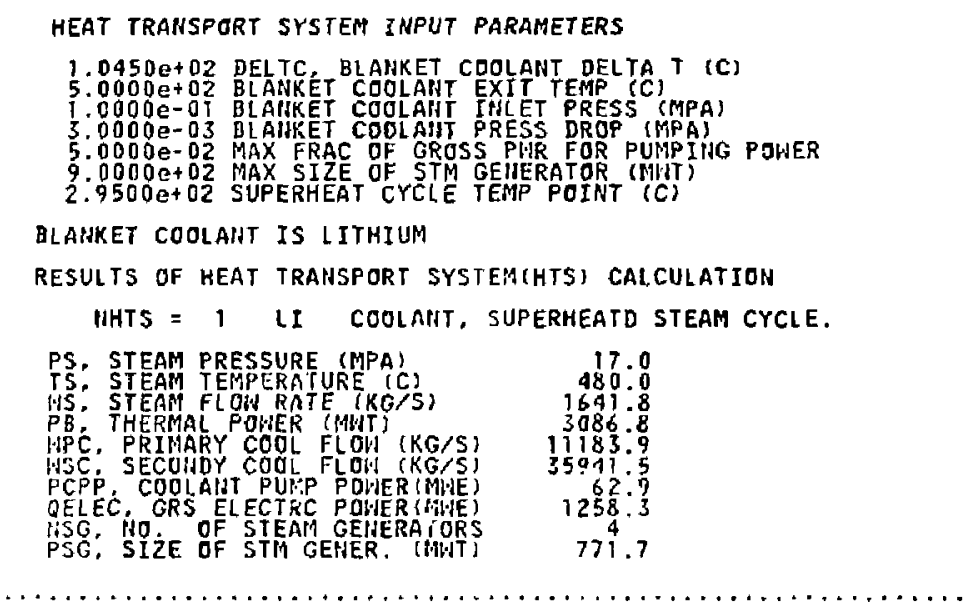

COSTS FOR THE HTS COMPONENTS (M\$) ....

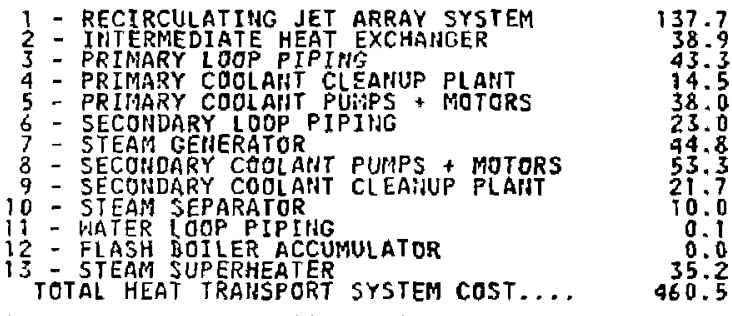

INPUT IO POWER COHYERSION MODEL MH.
PTGMAX, MAX TG UHIT SIZE. MHE
FELBOP, FRACTIOH OF GROSS MWE TO RUN BOP

OUTPUT FROH POWER COWWERSIOH MODEL (MMHE) 1258.3

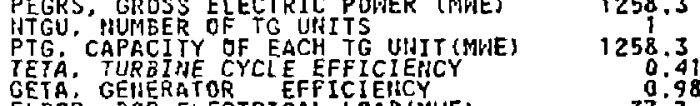
ELBOP, BOP ELECTRICAL LOAD(MWE)

SUPERHEAT CYCLE SELECTED

ELECTRIC PQUER (MHE) BALAIICE... GROSS ELECTRIC POHER

GEHL FOHER CONSUMED

DRIVER POHER COISUMED

NON-PUMP BOP POWER CONSUMED PET EIECTRIC PUWER

1258.3
85.4
74.2
37.7
1061.0

HEAT REJECTED FROM TURBIHE CYCLE (MWT) = 1828.5

Figure A-7, (Continued.) 
VOLUME OF BUILDINGS AND STRUCTURES

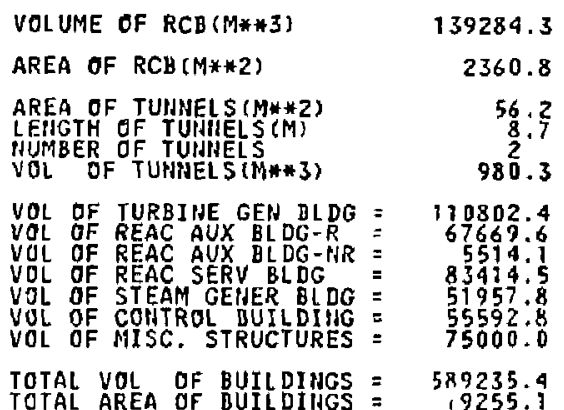

INDIVIDUAL COSTS IN ACCOUNT 21.06 (N\$) ...

REAC AUX BLDG.R

REAC AUX BLDG.HR

REAC SERV BLDG

COIITROL BLDG

DIRECT COIV BLDG

MISC STRUCTURES

TUNAEL IN $21.06 \ldots$

21.2

$2 \frac{2}{3}+6$

20.3

20.3

17.5

100.8

REACTOR PLANT EQUIPMENT COSTS (MS) ....

$\begin{array}{lr}\text { TRACK ING ALIGN SYSTEMS } & 27.4 \\ \text { FIRSI WALL SYSTEMS } & 2.3 \\ \text { IEXIRACTION SYSTEMS } & 24.13 \\ \text { BLAIKET AND SHIELD } & 57.6 \\ \text { HEAT TRANSPORT SYSTEM } & 460.5 \\ 22.00 \text { TOTAL RPE COST } & 572.4\end{array}$

TURBINE PLANT EQUIPMENT COSTS (MS)....

23.01 TURB INE GENERATORS

23.02 NOT CURRENTLY USED

23.05 CONDENSING SYSTEMS

23.04 FEED HEATING SYSTEMS

23.06 INSTRUMT EQNIPMENTROL

23.07 MISCELLAHEDUS ITEMS

124.3

23.00 TOTAL JPE COST

32.2
22.7
22.7
7.9

214.8

Figure A-7. (Continued.) 
ELECTRIC PLANT EQUIPMENT COSTS (M\$)....

$\begin{array}{llr}24.07 & \text { SWITCHGEAR } & 12.3 \\ 24.02 & \text { STATIOH SERYICE EQUIP } & 18.5 \\ 24.03 & \text { SWITCHBOARDS } \\ 24.04 & \text { PROTECT IVE EQIPMENT } & 3.8 \\ 24.05 & \text { ELECT STRUCTS + WIRHG } & 26.5 \\ 24.06 & \text { POWER + CORTRL WIRING } & 22.9 \\ 24.00 & \text { TOTAL EPE COST } & 85.1\end{array}$

MISCELLAHEOUS PLANT EQUIPMENT COSTS (M\$)....

\begin{tabular}{|c|c|}
\hline $\begin{array}{l}25.01 \\
25.02 \\
25.03 \\
25.04 \\
25.05\end{array}$ & 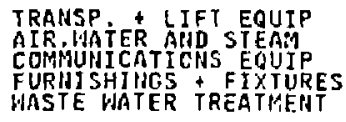 \\
\hline 5,00 & TOTAL MPE COSTS \\
\hline
\end{tabular}

MAIN HEAT REJECTION SYSTEM COSTS (M\$)..

26.01 COST OF STRUCTURES
26.02 MECHANICAL EQUIPMEHT

26.00 TOTAL MHRE COST 34.9

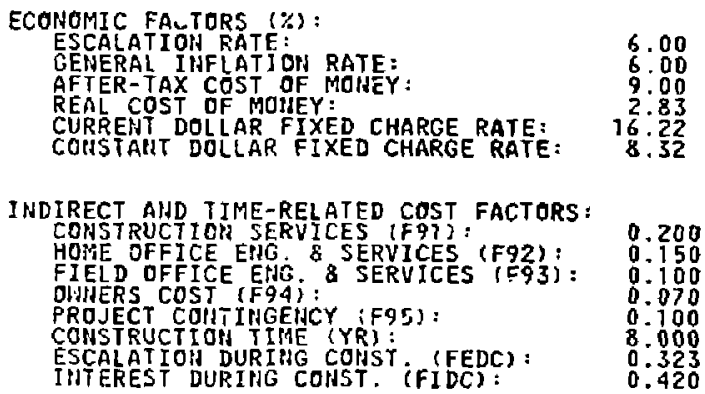

Figure A-7. (Continued.) 


\begin{tabular}{|c|c|c|c|}
\hline ACCOUNT & $\begin{array}{l}\text { ICF ECONOMIC EVALUATION FOR, UNIT POWER } \\
\text { ACCOUNT TITLE }\end{array}$ & \multicolumn{2}{|l|}{ (n) } \\
\hline 20 & LAHD AND LAND RIGHTS & \multicolumn{2}{|r|}{5.0} \\
\hline 21 & STRUCTURES AND IMPROVEMEIITS & \multicolumn{2}{|r|}{262.7} \\
\hline 22 & REACTOR PLAHT EOUIPMENT & \multicolumn{2}{|r|}{572.4} \\
\hline 23 & TURBIHE PLAIIT EOUIPMENT & \multicolumn{2}{|r|}{214.8} \\
\hline 24 & ELECTRIC PLANT EQUTPMEHT & \multicolumn{2}{|r|}{85.9} \\
\hline 25 & MISCELLANEOUS PLANT EQUIPMENT & \multicolumn{2}{|r|}{55.2} \\
\hline 26 & MAIH KEAT REJECTIOH EOUIPMENT & \multicolumn{2}{|r|}{34.9} \\
\hline 27 & DRIVER EQUIPMENT & \multicolumn{2}{|r|}{509.4} \\
\hline$\because 8$ & TARGET FACTORY EQUIPMENT & \multicolumn{2}{|c|}{76.9} \\
\hline & TOTAL DIRECT COST & \multicolumn{2}{|c|}{1816.3} \\
\hline 91 & COHSTRUCTIOH SERVICES & \multicolumn{2}{|c|}{363.3} \\
\hline 92 & HOME OFFICE EHGIHEERIHG AND SERVICES & \multicolumn{2}{|c|}{272.4} \\
\hline 93 & FIELD OFFICE ENGIUEERING AHD SERVICES & \multicolumn{2}{|c|}{181.6} \\
\hline 94 & OHMER'S COST & \multicolumn{2}{|c|}{127.1} \\
\hline \multirow[t]{3}{*}{95} & PROJECT CONTIMGEICY & \multicolumn{2}{|c|}{276.1} \\
\hline & TOTAL OVERNIGHT COST & \multicolumn{2}{|c|}{3036.9} \\
\hline & & CURREHTS & CONSTANTS \\
\hline 96 & ESCALATIOH DURIHG COHSTRLCTION & 980.7 & 0.0 \\
\hline \multirow[t]{4}{*}{97} & IHTEREST DURIHG COHSTRUCTIOH & 1275.6 & 283.7 \\
\hline & TOTAL CAPITAL COST & 5292.5 & 3320.6 \\
\hline & $\begin{array}{l}\text { COST OF ELECTRICITY } \\
\text { CAPITAL } \\
\text { FUEL } \\
\text { OBM } \\
\text { TOTAL }\end{array}$ & $\begin{array}{r}13.20 \\
0.03 \\
4.35 \\
17.58\end{array}$ & $\begin{array}{l}9.24 \\
0.01 \\
1.90 \\
5.65\end{array}$ \\
\hline & $\begin{array}{l}\text { COHSTANT \$ RESULTS IN } 1985 \text { DOLLARS } \\
\text { CURRENT } \$ \text { RESULTS IN } 1993 \text { DOLLARS }\end{array}$ & & \\
\hline
\end{tabular}

Figure A-7, (Continued.) 
APPENDIX B:

ALPHABETICAL LIST OF VARIABLES

This Appendix lists all variables used by SAFIRE in the COMMON blocks and the NAMELIST statements and the assoclated page numbers in this User's Manual.

LIST OF VARIABLES

\begin{tabular}{|c|c|c|c|}
\hline VARIABLE & COMMON BLOCK & NAMELIST & PAGE \\
\hline ABLDG & CMELDG & & 13 \\
\hline ACCOST & OUTT & & 21 \\
\hline ACCT & COUTT & & 15 \\
\hline ALICBM & PLANTI & & 24 \\
\hline ADCEXR & PLANTI & & 24 \\
\hline ADCFAT & PLANTI & & 24 \\
\hline ADCRV & PLANTI & & 24 \\
\hline ADCTRK & PLANTI & & 24 \\
\hline ADCWAL & PLANTI & & 24 \\
\hline ALPH & CURTAN & LMWIN & 16,39 \\
\hline ALPHI & CURTAN & LMWIN & 16,39 \\
\hline ALPHEL & TRITI & FUEL & 30,38 \\
\hline ALPHYL & TRITI & FUEL & 30,38 \\
\hline ALPSAR & CAVIT3 & CBANDS & 10,34 \\
\hline ANOT & DRIVER & DSYST & 18,37 \\
\hline AOCWAL & PLANTI & & 24 \\
\hline APSB & CMBLDG & & 13 \\
\hline ARCB & CMBLDG & & 13 \\
\hline ASSAY 6 & TEXTRI & FUEL & 29,38 \\
\hline ASTRLO & CAVITI & & 9 \\
\hline ASTRLT & CAVITI & & 9 \\
\hline ATITLE & COUTT & . & 15 \\
\hline ATOCBH & PLANTI & & 24 \\
\hline ATUN & OUTT & & 21 \\
\hline AUXPH & CURTAN & & 16 \\
\hline AWLIFA & CAVIT3 & & 10 \\
\hline AWLIFE & CAVIT2 & & 10 \\
\hline AWLIFN & CAVIT2 & & 10 \\
\hline BFPWRT & PLANTI & & 24 \\
\hline BFUSPR & CAVIT4 & & 11 \\
\hline BNOT & DRIVER & DSYST & 18,37 \\
\hline $\mathrm{Cl}$ & CAVITY & CBANDS & 12,34 \\
\hline $\mathrm{C} 2$ & CAVITY & CBANDS & 12,34 \\
\hline$c 3$ & CAVITY & CBANDS & 12,34 \\
\hline $\mathrm{C4}$ & CAVITY & CBANDS & 12,34 \\
\hline C5 & CAVITY & CBANDS & 12,34 \\
\hline C6 & CAVITY & CBANDS & 12,34 \\
\hline C7 & CAVITY & CBANDS & 12,34 \\
\hline
\end{tabular}




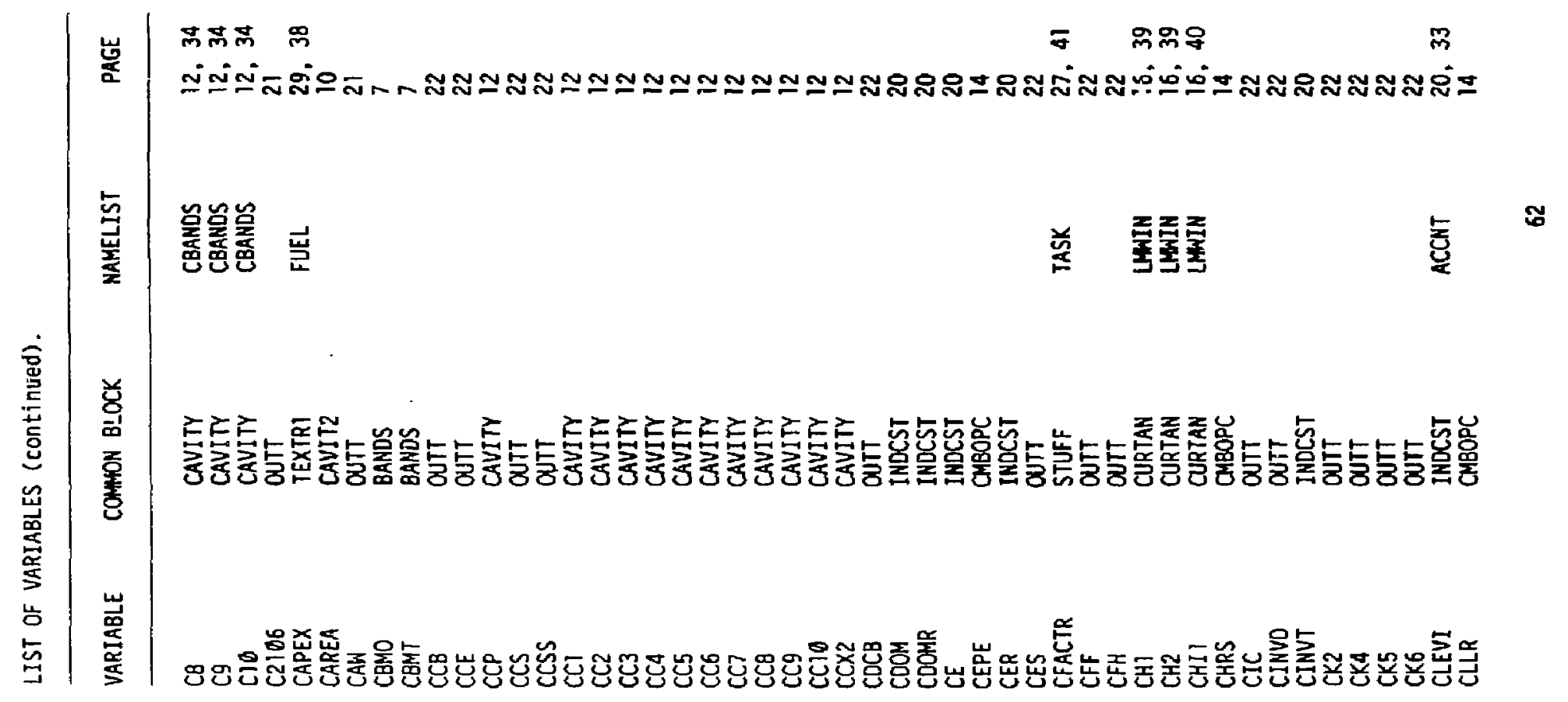




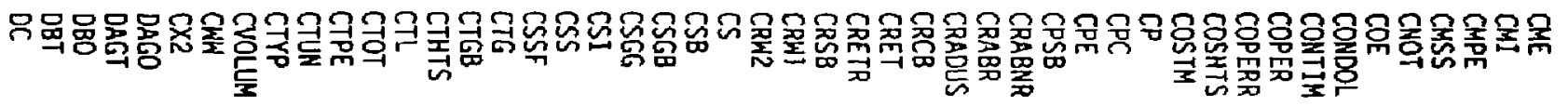

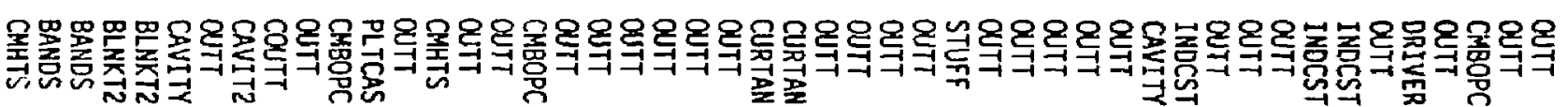

ฐึ

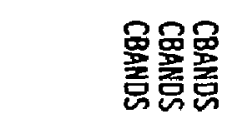

鼓

吕

解虽

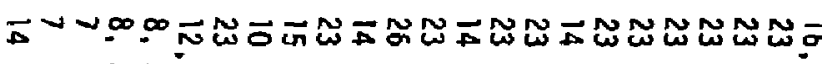
岕㟔出

효

w

wi 
LIST OF VARIABLES (continued).

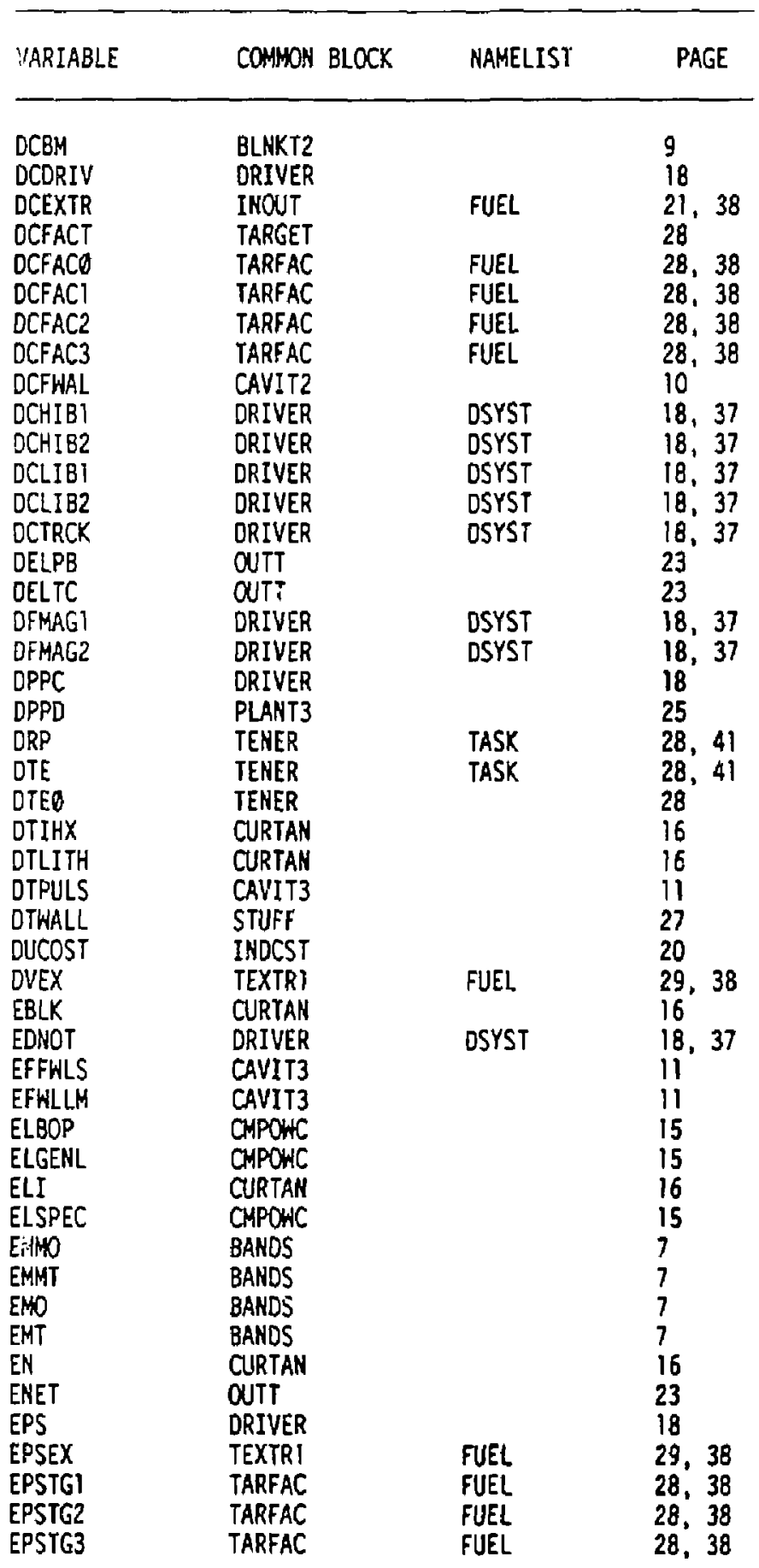


LIST OF VARIABLES (continued).

\begin{tabular}{|c|c|c|c|}
\hline VARIABLE & CONHON BLOCK & NAMELIST & PAGE \\
\hline ERATE & INDCST & ACCNT & 20,33 \\
\hline ETA & TARI & TASK & 27,41 \\
\hline ETAD & DRIVER & DSYST & 18,37 \\
\hline ETAEX & TEXTRI & FUEL & 29,39 \\
\hline ETAHIB & DRIVER & & 18 \\
\hline ETANOT & DRIVER & DSYST & 18,37 \\
\hline ETAREM & TEXTRI & & 29 \\
\hline EXTEMP & OUTT & & 23 \\
\hline F & CURTAN & & 16 \\
\hline FBURN & TRITI & FUEL & 30,39 \\
\hline FCCOMS & INOCST & ACCNT & 20,33 \\
\hline FCDEP & INDCST & ACCNT & 20,33 \\
\hline FCPEFS & INDCST & ACCNT & 20,33 \\
\hline FCRATE & INDCST & & 20 \\
\hline FCRATR & INDCST & & 20 \\
\hline FEGRS & CMPOHC & & 15 \\
\hline FELBOP & OUTT & & \\
\hline F[N] & CURTAK & LMWIN & 16,40 \\
\hline FLONG & CAVIT2 & & 10 \\
\hline FLOOP & PLANTI & CBANDS & 24,35 \\
\hline rLOW & CURTAN & & 16 \\
\hline FLU & CAVITY & & 13 \\
\hline FLUFW & CAVIT2 & CBANDS & 10,35 \\
\hline FLLOPT & DRIVER & DSYST & 18,37 \\
\hline FLLISTO & CAVIT2 & CBANDS & 10,35 \\
\hline FLUSTT & CAVIT2 & CBANDS & 10,35 \\
\hline FLWIHX & CURTAN & & 16 \\
\hline FMIN & CURTAN & LNHIN & 16.40 \\
\hline FNUM & ORIVER & & 18 \\
\hline FNUMAX & DRIVER & DSYST & 19,37 \\
\hline FOCUSL & DRIVER & & 19 \\
\hline FPOHER & POWBAL & TASK & 26,41 \\
\hline FPHRPT & PLANTI & & 2435 \\
\hline FRECON & CAVIT3 & CBANDS & 11,35 \\
\hline FSHORT & CAVIT3 & CBANDS & 11.35 \\
\hline FUELC & INDCST & & 20 \\
\hline FUELCR & INDCST & & 20 \\
\hline FWCO & BANDS & & 7 \\
\hline FWCT & BANDS & & 7 \\
\hline FWPWR & CAVIT4 & & 11 \\
\hline FWPWRA & CAVIT2 & & 10 \\
\hline FWPWRT & PLANT2 & & 25 \\
\hline FWT & CAVITI & & 9 \\
\hline $\mathrm{Fl}$ & CURTAN & LMHIN & 16,40 \\
\hline $\mathrm{F2}$ & CURTAN & LWWIN & 16,40 \\
\hline$F 3$ & CURTAN & LMWIN & 16,40 \\
\hline F4 & CURTAN & LWWIN & 16,40 \\
\hline
\end{tabular}


LIST OF VARIABLES (continued).

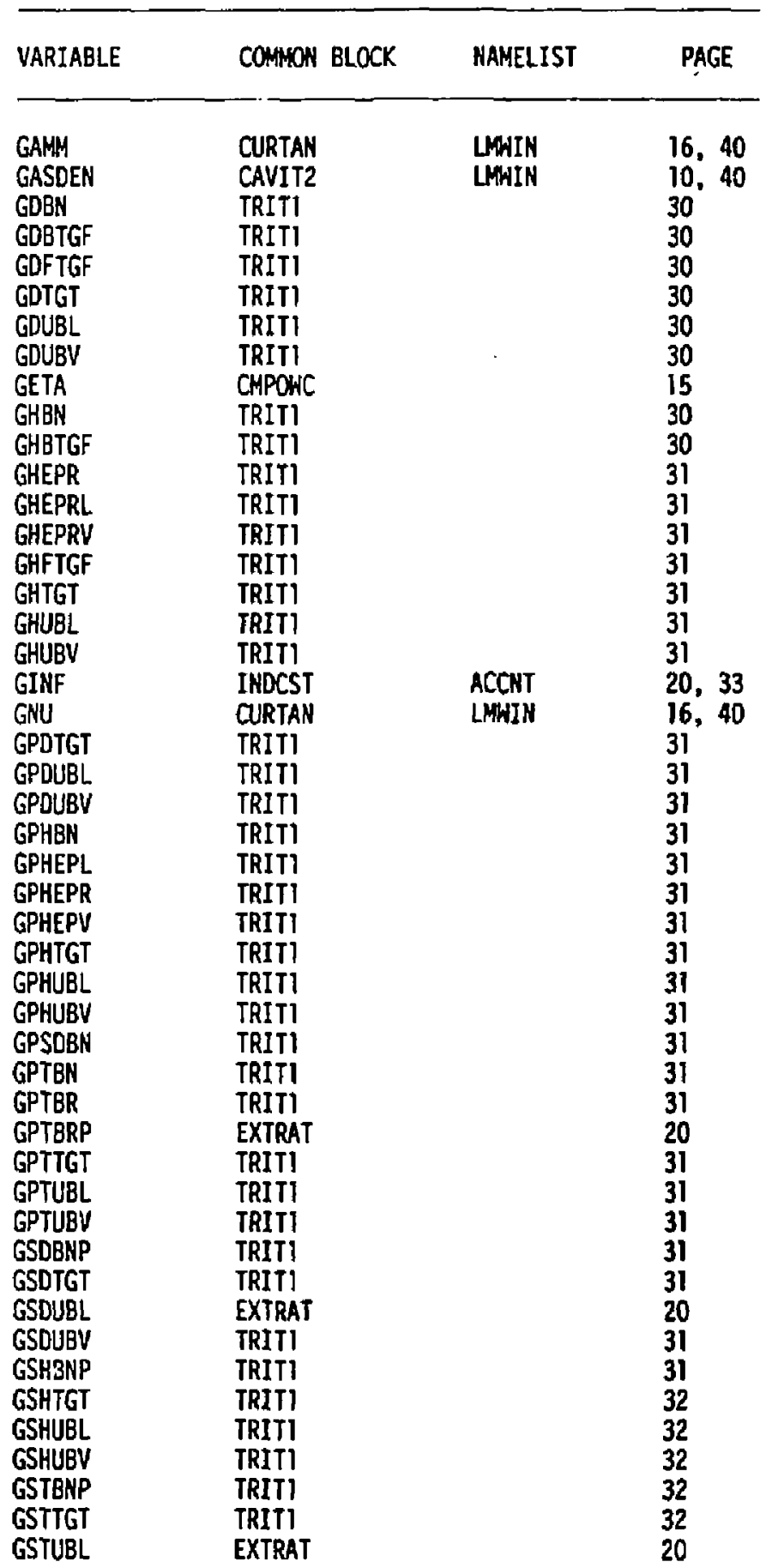


LIST OF VARIABLES (continued).

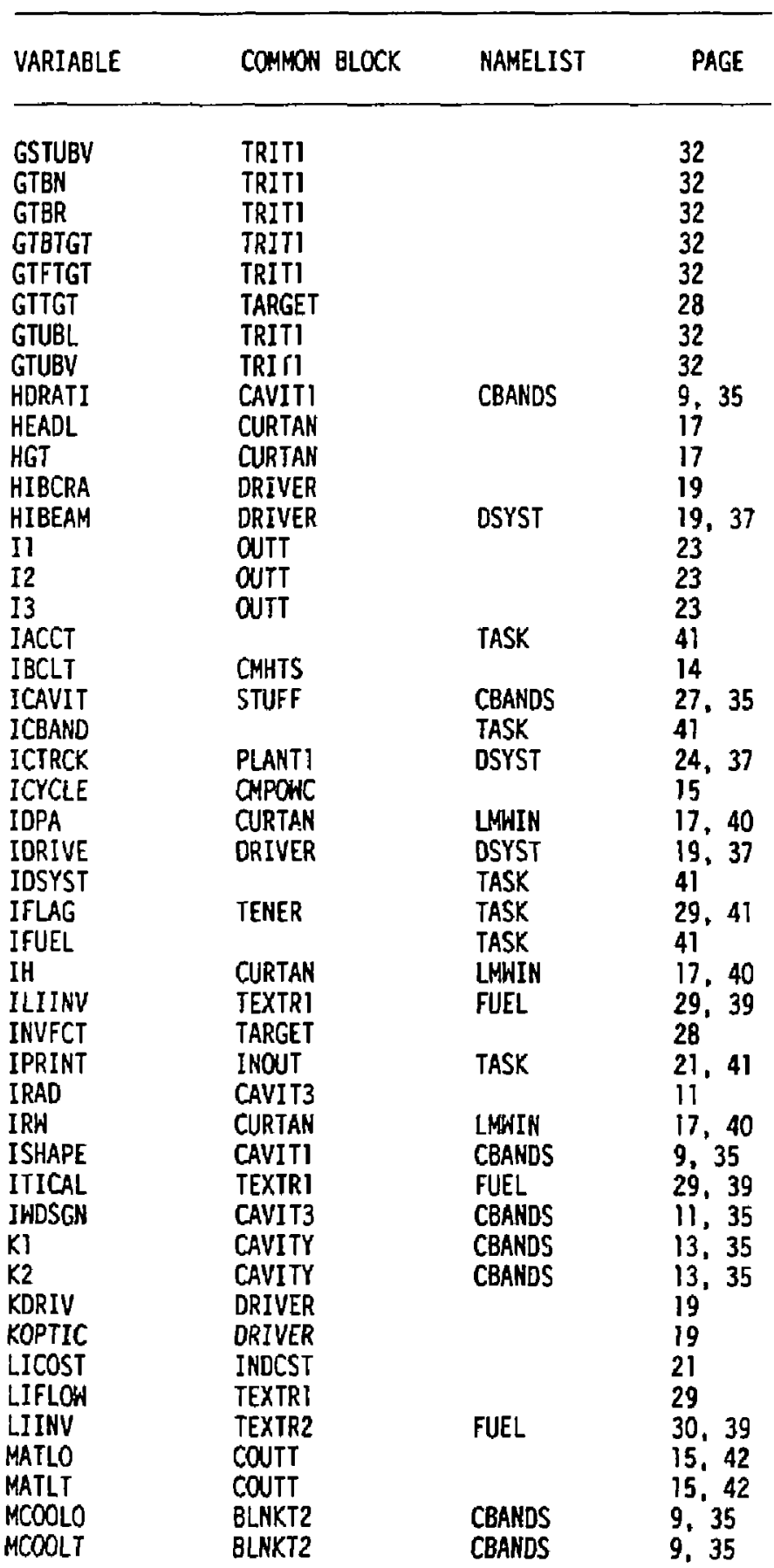


LIST OF VARIABLES (continued).

\begin{tabular}{|c|c|c|c|}
\hline VARIABLE & COMHON BLOCK & MAMELIST & PAGE \\
\hline MINRAD & CAVIT3 & CBANDS & 11,35 \\
\hline MLOSS & CAVIT3 & & 11 \\
\hline MNHLLD & CAVIT2 & & 10 \\
\hline MOLEBN & TRITI & & 32 \\
\hline HSTROI & BLHKT2 & CBANDS & 9. 35 \\
\hline HSTRO2 & BLHKT2 & CBANDS & 9.35 \\
\hline MSTR03 & BLNKT2 & CBANDS & 9,35 \\
\hline MSTRO4 & BLNKT2 & CBANDS & 9,35 \\
\hline MSTRTI & BLNKT2 & CBANDS & 9,36 \\
\hline MSTRT2 & BLNKT2 & CBAHDS & 9,36 \\
\hline MSTRT3 & BLNKT2 & CBANDS & 9,36 \\
\hline MSTRT4 & BLNKT2 & CBANDS & 9,36 \\
\hline NADD & PLANTI & & 24 \\
\hline NBEAM & DRIVER & DSYST & 19,37 \\
\hline NCAVIT & STUFF & CBANDS & 27,36 \\
\hline NDRIVE & STUFF & DSYST & 27,37 \\
\hline NLOOP & CHPOHC & & 15 \\
\hline NN & OUTT & & 23 \\
\hline NSG & CMHTS & & 14 \\
\hline NTGTFC & TARGET & FUEL & 28,39 \\
\hline NTGU & CMPONC & & 15 \\
\hline NUM & TENER & & 29 \\
\hline NUMM & TENER & & 29 \\
\hline NUNIT & INDCST & ACCNT & 21,33 \\
\hline NXTRAC & PLANT4 & & 25 \\
\hline NYEAR & RIHF & ACCHT & 26,33 \\
\hline NYRBNK & INOUT & CBANDS & 21.36 \\
\hline NYRDCA & INOUT & CBANDS & 21,36 \\
\hline NYREX & INOUT & FUEL & 21,39 \\
\hline NYRHIB & DRIVER & DSYST & 19,37 \\
\hline NYRLIB & DRIVER & DSYST & 19,37 \\
\hline NYRSWL & DRIVER & DSYST & 19,38 \\
\hline NYRTF & INOUT & FUEL & 21,39 \\
\hline NYRTRC & INOUT & DSYST & 21,38 \\
\hline OСВМО & BANDS & & 7 \\
\hline OCBMT & BANDS & & 7 \\
\hline OCFHAL & CAVIT2 & & 10 \\
\hline ODL & ORIVER & DSYST & 19,38 \\
\hline OPIICL & DRIVER & DSYST & 19,38 \\
\hline OPTICR & DRIVER & & 19 \\
\hline OPTLIF & DRIVER & DSYST & 19,38 \\
\hline PB & CNHTS & & 14 \\
\hline PBLIK & CURTAN & & 17 \\
\hline PCENT & INDCST & & 21 \\
\hline PCNOT & ORIVER & DSYST & 19.38 \\
\hline PCPP & CMHTS & & 14 \\
\hline PDENSO & BANDS & & 7 \\
\hline PDENST & BANDS & & 7 \\
\hline
\end{tabular}


LIST OF VARIABLES (continued).

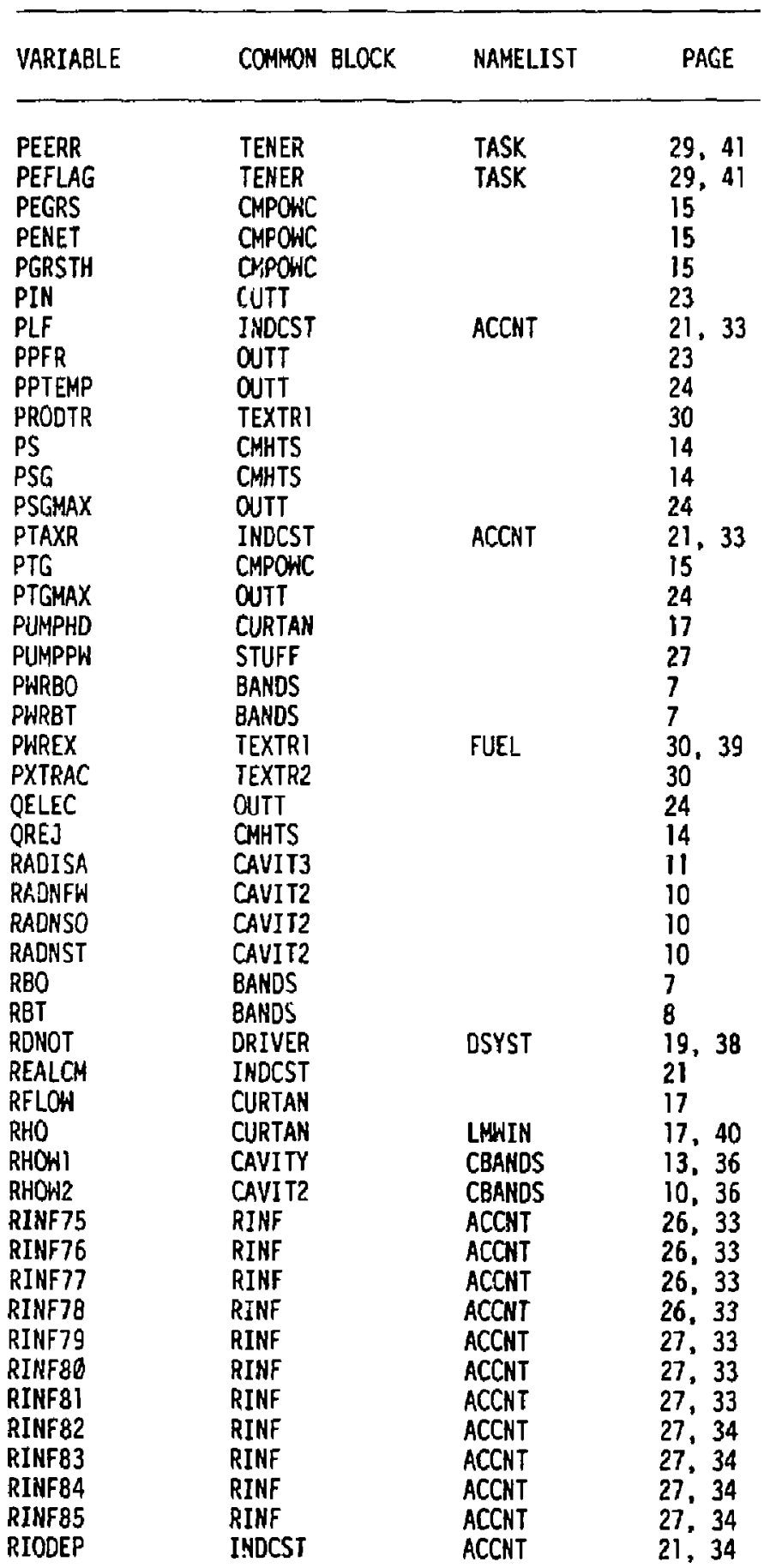


LIST OF VARIABLES (continued).

\begin{tabular}{|c|c|c|c|}
\hline VARIABLE & COAMON BLOCK & NAMELIST & PAGE \\
\hline $\begin{array}{l}\text { RO } \\
\text { ROSO } \\
\text { ROST } \\
\text { RPFLAG } \\
\text { RPO } \\
\text { RPRATE } \\
\text { RRCONS } \\
\text { RRFCT } \\
\text { RRFCTO } \\
\text { RRHOWI } \\
\text { RRHOW? } \\
\text { RRPD } \\
\text { RRPEFS } \\
\text { RRPLT } \\
\text { SALREM } \\
\text { SANGL } \\
\text { SCT } \\
\text { SHELL } \\
\text { SI } \\
\text { SIGMA } \\
\text { SIMP } \\
\text { SSID } \\
\text { SSIH } \\
\text { SSIT } \\
\text { STH } \\
\text { STRLFO } \\
\text { STRLFT } \\
\text { SUMT } \\
\text { SY } \\
\text { TO } \\
\text { TAU } \\
\text { TAUFAC } \\
\text { TAUNOT } \\
\text { TAXR } \\
\text { TCOST } \\
\text { TCUPC } \\
\text { TCUPP } \\
\text { TOCBM } \\
\text { TDCDRI } \\
\text { TDCEXT } \\
\text { TDCFAC } \\
\text { TOCPCA } \\
\text { TDCPLN } \\
\text { TDCTRC } \\
\text { TDCWAL } \\
\text { TDP } \\
\text { TEFLAG } \\
\text { TEMH }\end{array}$ & $\begin{array}{l}\text { CURTAN } \\
\text { BANDS } \\
\text { BANDS } \\
\text { TENER } \\
\text { TENER } \\
\text { PONBAL } \\
\text { INDCST } \\
\text { TARFAC } \\
\text { TARFAC } \\
\text { CAVITY } \\
\text { CAVITY } \\
\text { DRIVER } \\
\text { INDCST } \\
\text { PLANTI } \\
\text { BLNKTI } \\
\text { DRIVER } \\
\text { COUTT } \\
\text { TARI } \\
\text { CURTAN } \\
\text { CURTAN } \\
\text { CURTAN } \\
\text { TEXTRI } \\
\text { TEXTRI } \\
\text { PLANT4 } \\
\text { CURTAN } \\
\text { CAVIT2 } \\
\text { CAVIT2 } \\
\text { OUTT } \\
\text { CURTAN } \\
\text { CAVIT3 } \\
\text { DRIVER } \\
\text { TARFAC } \\
\text { DRIVER } \\
\text { INDCST } \\
\text { CURTAN } \\
\text { PLANTI } \\
\text { PLANTI } \\
\text { PLANT2 } \\
\text { PLANT5 } \\
\text { PLANT5 } \\
\text { PLANT5 } \\
\text { PLNT } \\
\text { PLNT } \\
\text { PLANT55 } \\
\text { PLANT5 } \\
\text { PLANT2 } \\
\text { TENER } \\
\text { BANDS }\end{array}$ & $\begin{array}{l}\text { TASK } \\
\text { TASK } \\
\text { ACCNT } \\
\text { FUEL } \\
\text { ACCNT } \\
\text { TASK } \\
\text { LMHIN }\end{array}$ & 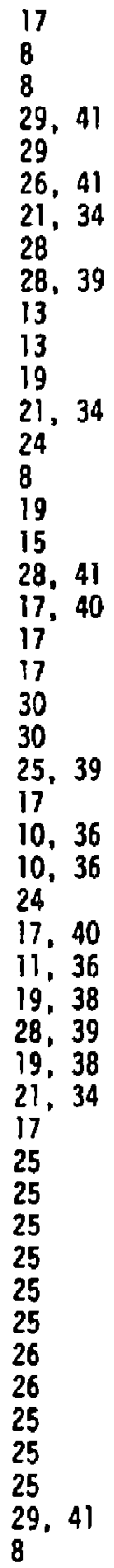 \\
\hline
\end{tabular}




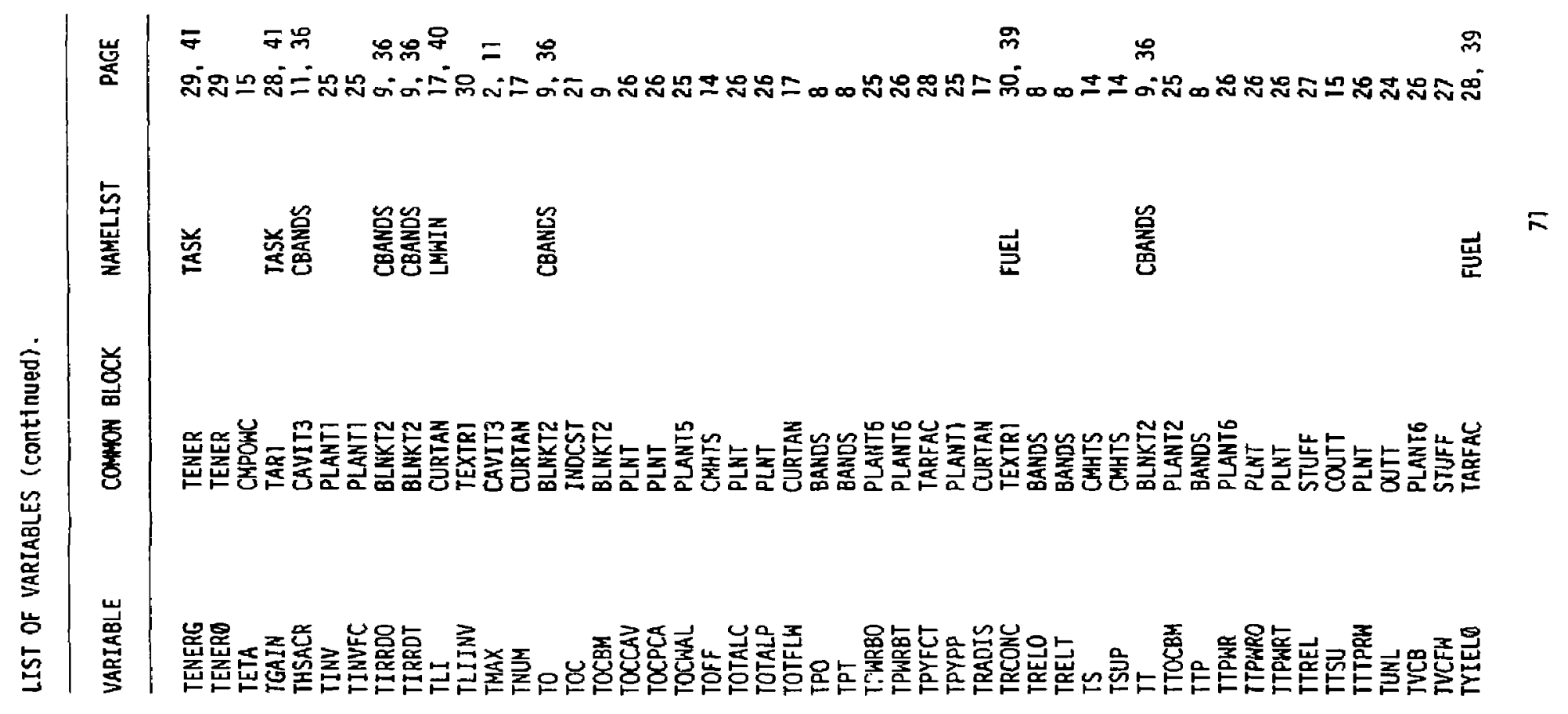


LIST OF VARIABLES (continued).

\begin{tabular}{|c|c|c|c|}
\hline VARIABLE & COMINON BLOCK & NAMELIST & PAGE \\
\hline $\begin{array}{l}\text { TYIELD } \\
\text { TEBR }\end{array}$ & $\begin{array}{l}\text { POWBAL } \\
\text { INOCST }\end{array}$ & TASK & 26,41 \\
\hline UU & CURTAN & LMHIN & 17,40 \\
\hline UCOBSO & BANDS & & 8 \\
\hline UCOBST & BANDS & & 8 \\
\hline VBC & CNBLOG & & 13 \\
\hline VBLOG & CHBLOG & & 13 \\
\hline VBO & BANOS & & $B$ \\
\hline VBSRO & BANDS & & 8 \\
\hline VBSRT & BANOS & & 8 \\
\hline VBT & BANDS & & 8 \\
\hline VCB & CMHTS & & 14 \\
\hline VCBO & TEXTR3 & & 30 \\
\hline VCBT & TEXTR3 & & 30 \\
\hline VELINJ & CURTAN & & 17 \\
\hline VELMP & CURTAN & & 17 \\
\hline VFBSO & BANDS & & 8 \\
\hline VFBST & BANDS & & 8 \\
\hline VFFWC & CAVIT3 & CBAKDS & 11,36 \\
\hline VFFWS & CAVIT3 & CBANOS & 11,36 \\
\hline VMSS & CABLDG & & 13 \\
\hline VOLCHB & CURTAN & & 18 \\
\hline VOLHD & STUFF & & 27 \\
\hline VOLPIP & SIUFF & & 27 \\
\hline VPSB & CMBLOG & & 13 \\
\hline VRABNR & CMBLDG & & 13 \\
\hline VRABR & CABLDG & & 13 \\
\hline VRCB & CABLDG & & 13 \\
\hline VRSB & CHBLDG & & 13 \\
\hline VSGB & CHBLDG & & 14 \\
\hline VTGB & CMBLDG & & 14 \\
\hline VTUN & CMBLDG & & 14 \\
\hline WALLC & QURTAN & LMWIN & 18,40 \\
\hline HCAOJO & BANDS & & \\
\hline HCAOJT & BANDS & & 8 \\
\hline HCSTI & CAVITY & CBAHDS & 13,36 \\
\hline HCST2 & CAVIT2 & CBAHDS & 10,36 \\
\hline WLIFE & CAVIT3 & CBANDS & 11,36 \\
\hline WLOSS & CAVIT3 & & 11 \\
\hline HPC & OUTT & & 24 \\
\hline WS & CMHTS & & 14 \\
\hline WSC & OUTT & & 24 \\
\hline WHCSTI & CAVITY & & 13 \\
\hline WWCST2 & CAVITY & & 13 \\
\hline XFRAC & TEXTRI & & 30 \\
\hline XKI & CAVITY & & 13 \\
\hline$X K 2$ & CAVITY & & 13 \\
\hline
\end{tabular}


LIST OF VARIABLES (continued).

\begin{tabular}{llll}
\hline VARIABLE & COMMON BLOCK & NAMELIST & PAGE \\
\hline XL & CURTAN & & 18 \\
XLAMDA & CURTAN & LMNIN & 18,40 \\
X1 & CAVITY & CBANOS & 13,36 \\
X2 & CAVIT2 & CBANDS & 10,36 \\
XX1 & CAVITY & & 13 \\
XX2 & CAVITY & & 13 \\
YOUNGM & CURTAN & LMNIN & 18,40 \\
\hline
\end{tabular}

Wang document 0028E 